Portland State University

PDXScholar

$1-28-1977$

\title{
The Effect of Declining Timber Supplies and Productivity Increases in the Forest Products Industries Upon Employment in Douglas County, Oregon
}

Patrick L. Burden

Portland State University

Follow this and additional works at: https://pdxscholar.library.pdx.edu/open_access_etds

Part of the Forest Management Commons, and the Geography Commons Let us know how access to this document benefits you.

\section{Recommended Citation}

Burden, Patrick L., "The Effect of Declining Timber Supplies and Productivity Increases in the Forest Products Industries Upon Employment in Douglas County, Oregon" (1977). Dissertations and Theses. Paper 2495.

https://doi.org/10.15760/etd.2492

This Thesis is brought to you for free and open access. It has been accepted for inclusion in Dissertations and Theses by an authorized administrator of PDXScholar. Please contact us if we can make this document more accessible: pdxscholar@pdx.edu. 
AN ABSTRACT OF THE THESIS OF Patrick L. Burden for the Master of Science in Geography presented january 24, 1977.

Title: The Effect of Declining Timber Supplies and Productivity Increases in the Forest Products Industries Upon Employment in Douglas County, Oregon.

APPROVED BY MEMBERS OF THE THESIS COMMITTEE:

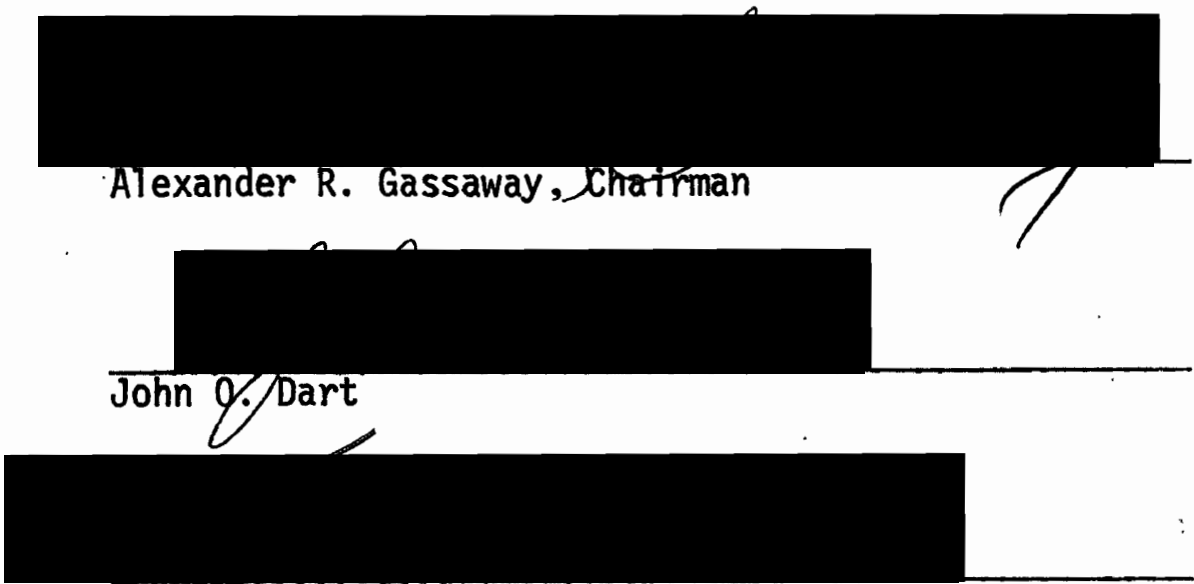

Thomas M. Poutsen

This thesis examines some of the factors that will have significant impact upon employment in Douglas County, Oregon to the year 2000. The major question this research attempts to answer is: Given a continuation of current policies and programs, what will future employment levels in the forest products industries and total employment levels in all industries in Douglas County be to the year 2000.

A commonly held belief by residents of the county is that a declining timber harvest will have a significant negative effect upon employment in the forest products industries and, thus, adversely affect 
total employment among all industries in the county. The author believes that two other factors have a more significant impact upon employment levels than has timber harvest:

1. The number of logs processed, or consumed, by wood products manufacturing firms in the county, and

2. The impact of increasing labor force productivity in the forest products industries.

The published data collected for use in this thesis are primarily from U.S. Forest Service publications. Other published materials were from the State of Oregon Forestry Department and Oregon State University School of Forestry. Excluding background materials, the data were in six primary areas:

1. An analysis of the economic base of Douglas County and the influence of the forest products industries,

2. Documentation of the complex intra-state flow of logs between counties, ownership classifications and user classifications,

3. A forecast of the possible timber harvests from Douglas County lands based upon the most recent inventory of timberlands in the county,

4. Studies of the future of the Tumber and wood products industry,

5. Interviews of local persons knowledgeable of the forest products industry, and

6. Personal observations and opinions obtained during the author's fifteen months of employment in Douglas County with the Coos, Curry, Douglas Economic Improvement Association. 
The major findings from this study are as follows:

1. The processing (or consumption) of logs in local manufacturing facilities is a more accurate indicator of forest products employment due primarily to the fact that manufacturing, and not logging (or harvest) is the major employer in the forest products sector.

2. Increased utilization of wood chips and increased imports of logs, principally from Bureau of Land Management holdings in adjacent counties, has resulted in increased forest products employment in Douglas County.

3. Approximately 50 percent of the annual forest industry harvest in Douglas County is exported to mills in adjacent counties. If the predicted deciine in harvest from private forest industry lands (which represents the major part of the decline) is evenly distributed among all owners in this classification, then the impact upon total log consumption in Douglas County may not be as severe as anticipated.

4. Given current policies and programs the availability of timber could remain fairly stable over the next two decades. The predicted reduction in the timber resource base in 19952005 could account for a loss of approximately 1,200 jobs or 15. percent of total employment in the forest products industries.

5. Labor force productivity increases are projected to account for 99 percent of the employment losses during the next two decades and for 75 percent in the third decade. Productivity 
4

increases could account for losses of approximately 1,100 jobs in the first decade, 2,800 in the second, and 3,400 in the third.

6. In the next thirty years Douglas County could lose over 50 percent of the present employment in lumber and wood products.

7. The impact that this could have upon the total economy of the county would be a maximum loss of 12,000 jobs. This figure is dependent upon the local economy retracting to the fullest extent possible, 
THE EFFECT OF DECLINING TIMBER SUPPLIES AND PRODUCTIVITY INCREASES

IN THE FOREST PRODUCTS INDUSTRIES UPON EMPLOYMENT

IN DOUGLAS COUNTY, OREGON

by

PATRICK L. BURDEN

A thesis submitted in partial fulfillment of the requirements for the degree of

MASTER OF SCIENCE

in

GEOGRAPHY

Portland State University

1977 
TO THE OFFICE OF GRADUATE STUDIES AND RESEARCH:

The members of the Committee approve the thesis of Patrick L. Burden presented January 28, 1977.

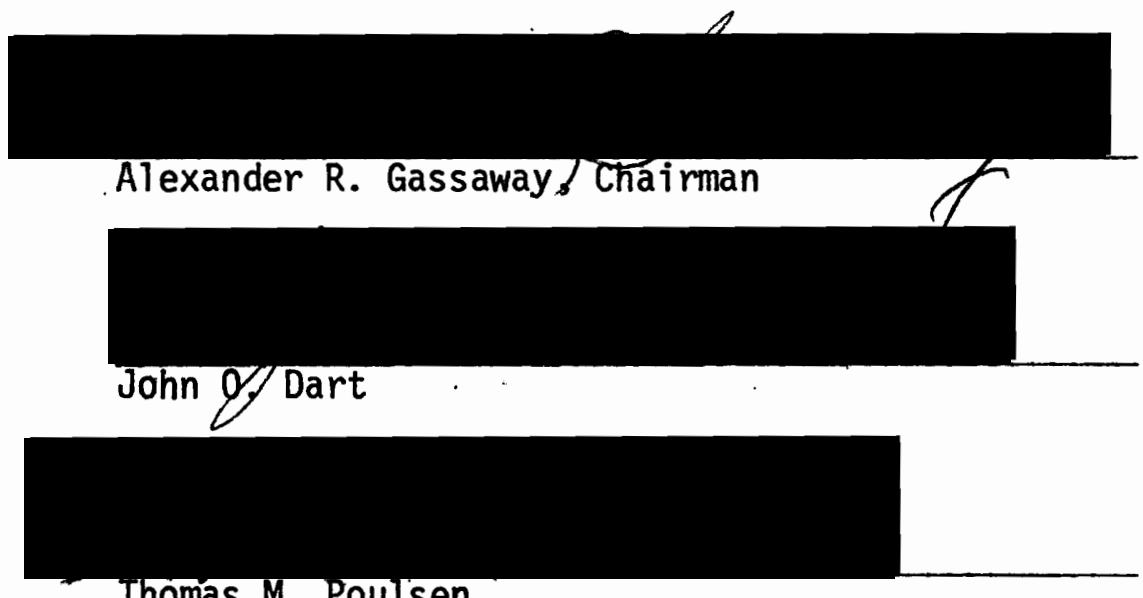

APPROVED:

D. Richard Lycan, Head, Department of Geography

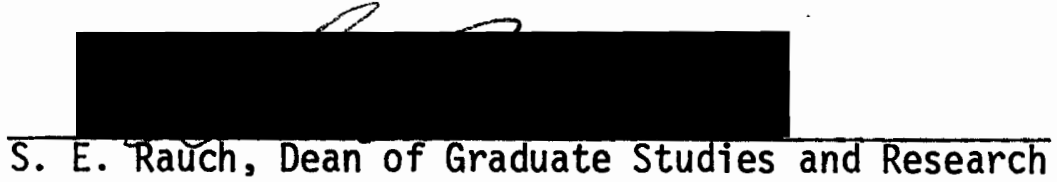




\section{ACKNOWLEDGEMENTS}

The number of persons who have contributed to this thesis is far too numerous to list, however I would like to personally thank the following individuals and organization for their supernumerary assistance: the members of my graduate committee, Dr. John Dart, Dr. Thomas Poulsen, and especially my patient advisor Dr. Alexander Gassaway for their laborious efforts in reviewing earlier drafts of this document; the staff of the Coos, Curry, Douglas Economic Improvement Association; Vangie Petersen, typist emeritus; Nadine White, Geography Department secretary, without whose help this process would have taken much longer; Merilee and Merrick, for love, understanding and innumerable sacrifices. 
TABLE OF CONTENTS

PAGE

ACKNOWLEDGEMENTS. ............................ $i$...

LIST OF TABLES ................................ vi

LIST OF FIGURES ................................... vii

CHAPTER

I INTRODUCTION. ...................... 1

The Problem ................. 1

Study objective ............. 4

II THE CHARACTER OF DOUGLAS COUNTY .......... 6

The Climate................ 7

History ................ g

Poputation ................. 10

Employment ................ 13

Manufacturing

Nonmanufacturing

III THE ECONOMIC BASE OF DOUGLAS COUNTY ......... 17

IV SELECTED FACTORS AFFECTING FUTURE TIMBER INDUSTRY EMPLOYMENT IN DOUGLAS COUNTY, OREGON . . . . . . . 24

A Declining Timber Harvest ......... 25

Timber Flows of Douglas County ....... 29

Productivity .................. 34 
V FUTURE FOREST PRODUCTS EMPLOYMENT . . . . . . . 36

Future Timber Consumption .......... 41

Future Timber Supplies . . . . . . . . . 44

Employment Changes .......... . 47

VI SUMMARY AND CONCLUSIONS ............. 56

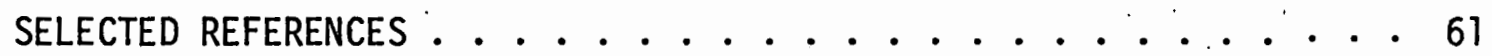

GLOSSARY .................... 66 


\section{LIST OF TABLES}

TABLE

PAGE

I Growth of Cities in Douglas County, Oregon, 1900-1970 . . 12

II Basic Industries of Douglas County, Oregon, 1970. . . . 18

III Dependency Upon Timber-Based Employment for Selected

Economic Areas in Western Oregon, 1970 . . . . . . 20

IV Forest Industry Multipliers for Douglas County, Oregon. . . 22

$V$ Average Multiplier Values and Ranges by County Employment

Size Classes................ 23

VI Timber Production by Timbershed for Three Timber Flow

Projections Shown as Ratios to 1968-1973 Annual

Average Harvest. ............... . . 30

VII Net Exports by Owner Class from Douglas County, Oregon. - . 31

VIII Percent Change in Productivity per Employee, $1960-1965$. . . 35

IX Timber Harvest and Consumption Data for Douglas County,

Oregon, 1966, 1968 and 1972........... 40

$X$ Log Consumption and Forest Products Employment in

Douglas County, Oregon .............. . 41

XI Average Annual Harvest in Douglas County, Oregon,

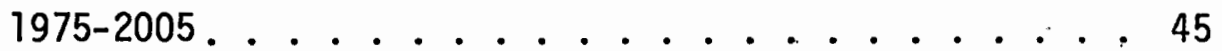

XII Projected Average Annual Log Consumption in Douglas,

County, Oregon by Owner Class, 1975-2005 ...... 47 
TABLE

XIII Potential Changes in Employment Levels in the Lumber and Wood Products Industry Due to Change in Log Consumption 1975-2005 .............. . . 48

XIV Log Consumption Patterns in Douglas County, Oregon by Industrial Sector as a Percentage of Total Consumption .................. 49

XV Sawmill and Veneer and Plywood Mill Consumption in Dougtas County, Oregon, 1975-2005 . . . . . . . 50

XVI Impacts of Reduced Timber Availability on Employment,

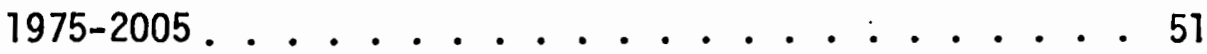

XVII Projected Employment Levels in Forest Products Industries 1975-2005 ............ . . 52

XVIII Projected Total Employment Changes in Douglas County as a Result of Changes in the Local Forest Products Sectors, 1975-2005.......... 55 


\section{LISTT OF FIGURES}

FIGURE

PAGE

1. Douglas County, Oregon ............. 2

2. Average Monthly Precipitation at Roseburg,

Douglas County, Oregon ........... 8

3. Average Monthly Temperatures at Roseburg,

Douglas County, Oregon ........... 9

4. Population Growth by Decade for Douglas

County, Oregon, 1870-1970 ......... 12

5. Wood Products Manufacturing Firms, 1970 ....... 13

6. Employment and Log Production in Douglas

County, Oregon, 1960-1975 .......... 14

7. Economic Areas in the Douglas-fir Region

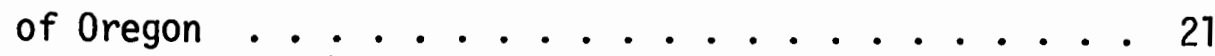

8. Hypothesized Aggregate Timber Supply and Demand . . . . . 25

9. Douglas County Timber Harvest, 1955-1974 . . . . . . . 27

10. Timberlands in Western Oregon ........... 33

11. Estimated Productivity Levels in the Forest

Products Industries of Western Oregon,

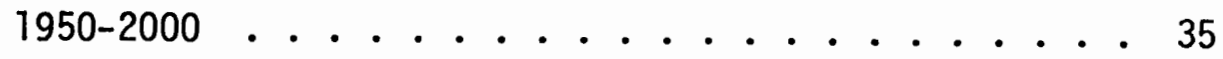

12. Linear Regression Forecast of Forest Products

Employment in Douglas County, 1975-1990 . . . . 37

13. Ratio of Lumber and Wood Products Employment to

Million Board Feet of Timber Harvested . . . . . 39 
CHAPTER I

INTRODUCTION

Douglas County lies in southwestern Oregon between the Pacific Ocean and the Cascade Mountain Range (Figure 1). This location places the county within the Douglas-fir region that includes western Oregon, western Washington, and northwestern California. Over the past century, the Douglas-fir region suppiied one-third of the industrial wood of the nation (U.S. Forest Service, 1973). Increasing demand for wood products, coupled with the large suppiy of raw material in the region, has created a major wood products industry in the Pacific Northwest.

\section{THE PROBLEM}

The major dependence of the economy of Douglas County, and the State of Oregon as a whole, upon the forest products industry has been, historically, a cause for concern. Shifting national demand for forest

products over time has dictated levels of production within the county and the subsequent employment derived from timber harvest and processing within the region. In 1975 this employment accounted for 27.2 percent of the total employment in the county. Indirectly, the income and employment of other sectors of the local economy, which are to some degree dependent upon employment in the forest products industry, were also affected by these cyclical phenomena.

Without a diversified industrial base to offset fluctuations in the dominant lumber and wood products industry, Douglas County is 


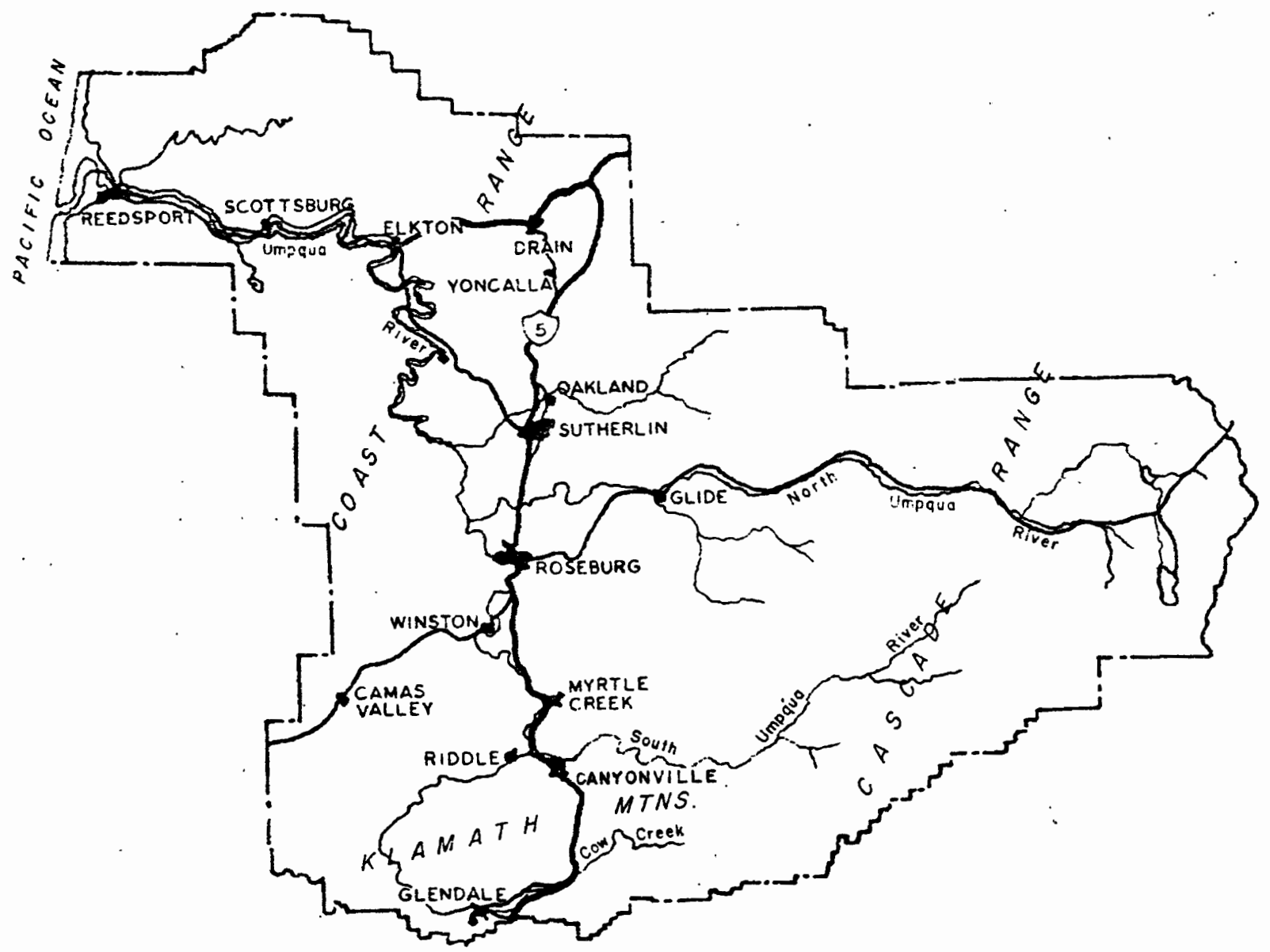

Figure 1. Douglas County, Oregon. 
extremely vulnerable to fluctuations in that sector. The local forest products industry however, is rapidly approaching a point in time when the national demand for wood products will not be the major determining factor of production and employment. According to projections of recent studies, the county is nearing the point where availability of local timber will be limiting forest products production and employment, and thus the local economy (Hami11, 1963; Gedney et a1., 1975; and Beuter et a1., 1976). Historic overcutting on private lands, an increasing demand for timber and a continued diversion of commercial timberlands to nonforest uses such as roads, urban development, agriculture, power transmission rights-of-way, or to other uses of the forest such as recreation and preservation are creating a shortage situation in all of southwestern Oregon.

The author initially became involved with the impact that this timber shortage may have upon the local economy as a consequence of his employment with the Coos, Curry, Douglas Economic Improvement Association (CCDEIA) in Roseburg, Oregon. The CCDEIA is an Economic Development District, funded by the U.S. Department of Commerce, Economic Development Administration, in concert with Coos, Curry and Douglas Counties. Its primary purpose is one of increasing employment opportunities for residents of the three county area. As part of its basic service program for local government entities and districts, the CCDEIA was asked by Umpqua Community College in Roseburg, Oregon to assist its staff in forecasting sectoral employment and population for Douglas County to the year 1990. The data to be generated would be used by the College in their 15 year planning program. The author 
utilized standard linear regression techniques to complete the forecast and, in addition, initiated and developed two scenarios of population and employment based upon gross estimates of the declining timber resource base in western Oregon. The results were not encouraging. The optimistic scenario projected that the 1975 population of 80,400 would remain at that level through 1990, whereas the pessimistic scenario predicted a decline of 15,400 persons to 65,000 or 18.8 percent by the same year.

The findings seemed to reinforce the commonly held belief by residents of Douglas County that a declining timber harvest will have a significant negative effect upon employment in the lumber and wood products industry which comprises 83.2 percent of total manufacturing employment in the county. However, later investigation by the author revealed that since 1968, increasing employment levels have been coupled with decreasing timber harvests. Such inconsistencies eventually led the author to undertake this study.

\section{STUDY OBJECTIVE}

The purpose of this thesis is to estimate the level of employment in the forest products and other industries in Douglas County to the year 2000. In so doing, the author will attempt to demonstrate that the level of timber harvested within the county is not the critical factor that so many residents believe it to be. Two other factors are believed by the author to have a more significant impact upon future employment levels than timber harvest:

1. The number of logs processed, or consumed, by wood products 
manufacturing firms in the county, and

2. The impact of increasing labor force productivity in the forest products industries.

This paper will attempt to demonstrate the relationships that presently exist between employment and these two major factors, and forecast the relationships as they might exist to the year 2000 . From these findings, an effort will be made to determine employment levels in the local forest products industries and for all industries in Douglas County.

Chapters II and III of this report provide a discussion of the general character and economic base of Douglas County to enable the reader to acquire a general background knowledge of the area under study. Chapter IV discusses the factors that affect timber supply and productivity increases, and contains the forecasts for these factors to the year 2000. In Chapter $V$, the methodology developed to predict employment levels is presented and utilized to estimate employment for the county to 2000. Chapter VI examines additional factors that may increase this estimate and presents the conclusions of the paper.

A list of terms that commonly prevail in the forestry literature, and which are used in this paper, are presented in the Glossary with their definitions as obtained from U.S. Forest Service publications. 


\section{CHAPTER II}

\section{THE CHARACTER OF DOUGLAS COUNTY}

of the 36 counties in the State of Oregon, Douglas County ranks fifth in area with 5,089 square miles, seventh in population with 80,400 as of 1975 , and has a population density of 15.8 persons per square mile. However, due to the local irregular topography and the large amount of federally owned land within the county, the amount of developable land is comparatively limited. Population in Douglas County is distributed primarily in the alluvial valleys of the Umpqua River system, largely between the Cascade Range on the east and the Coast Range on the west (Figure 1). Early transportation routes followed these rivers and subsequent settlement occurred on the relatively flat and fertile land paralleling them.

The North and South forks of the Umpqua River originate in the Cascade Range that forms the eastern part of the county. The west side of the Cascades rise in a generally long slope to an average summit elevation of 5,000 to 6,000 feet, with peaks exceeding 9,000 feet. Cow Creek, the third major tributary of the Umpqua, has its source in the $\mathrm{K} 7$ amath Mountain Range that averages 6,000 to 7,000 feet and forms the southern boundary of the county. The major area of level land, often called the Central Umpqua Valley, runs in a north-south axis through the center of the county, from the junction of Cow Creek and the South Umpqua to a point a few miles north of the North and South fork's confluence. Within this belt of land lies most of the arable land in the 
county, the larger populated places (including the largest, Roseburg, with 16,600 population), and the route of Interstate 5 . The Umpqua River continues in a northerly direction until a ridge of high ground that extends east from the Coast Range forces it to turn west through the 2,000 to 3,000 foot Coast Range and to the Pacific Ocean west of Reedsport.

\section{CLIMATE}

Douglas County has a temperate maritime climate with moderately warm summers and wet, mild winters. Differences in elevation are the major influence on variations in local climate. The outstanding characteristic of the county's climate is the seasonal distribution of precipitation as shown by Figure 2. About 60 percent of the local precipitation occurs between November and February, with only 10 percent during the summer months of June through September. Locally, the average annual precipitation varies from 24 inches in the principal river valley to extremes of over 100 inches in the coast Range. It is on these we11-watered mountain slopes that the abundant forests of Douglas County grow. Seasonal temperatures are moderate throughout much of the county, with the mountain peaks and higher elevations on the periphery of the area recording consistently lower averages. The average annual temperature at Roseburg is $54.6^{\circ} \mathrm{F}$, and seasonal variations are small in the inland valley area of the county as typified by this station (Figure 3 ).

Information from the Environmental Data Service (1974) indicates that only in the month of January have winter temperatures dropped 


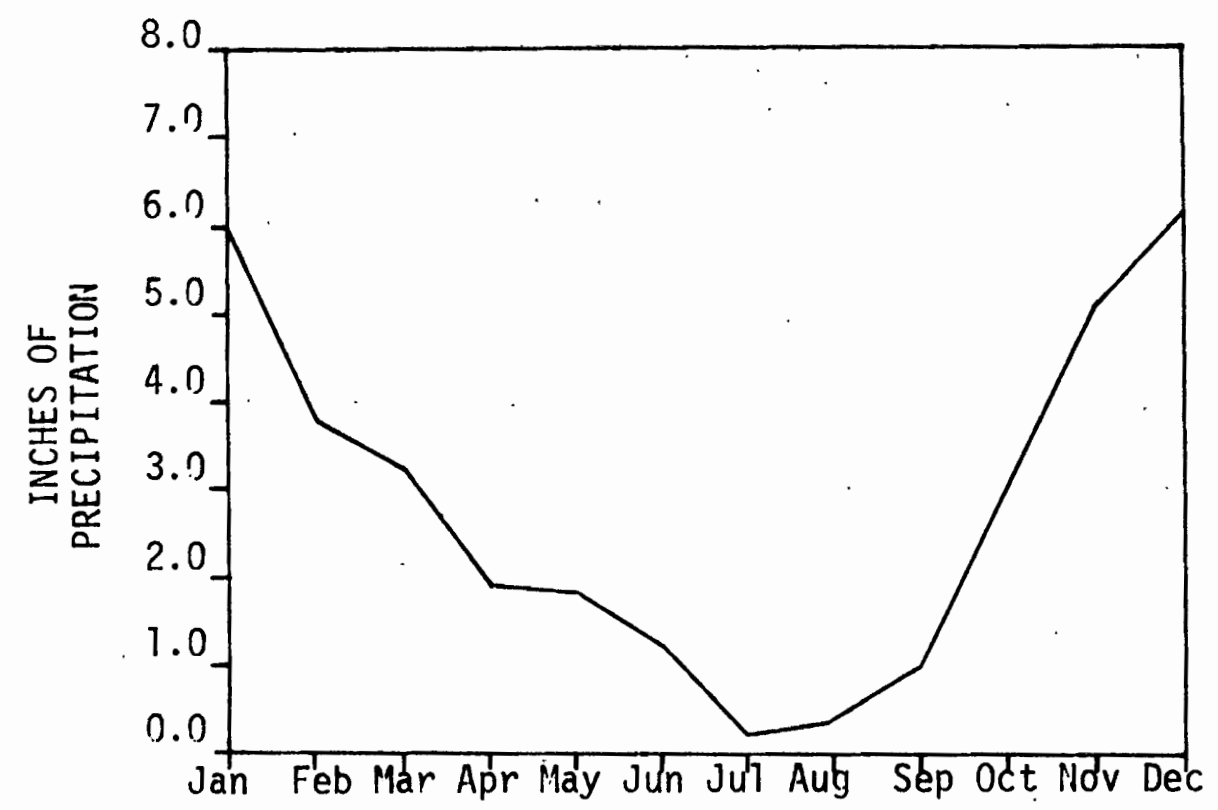

Figure 2. Average monthly precipitation at Roseburg, Douglas County, Oregon.

Source: Environmental Data Service, National Oceanic and Atmospheric Administration, 1974.

below $13^{\circ} \mathrm{F}$, with the minimum of $-7^{\circ} \mathrm{F}$ for Roseburg occurring in January 1959. The average daily minimum temperatures at Roseburg for the months of November through February, range from $33.4^{\circ} \mathrm{F}$ to $38.4^{\circ} \mathrm{F}$ as illustrated by Figure 3. Average daily maximum temperatures during the summer months of June through September range from $75.1^{\circ} \mathrm{F}$ to 84. $0^{\circ} \mathrm{F}$. A record maximum of $106.0^{\circ} \mathrm{F}$ was reached in July 1961. Along the coastal sections of the county seasonal variations are even smaller, with Reedsport having historic records of $96^{\circ} \mathrm{F}$ maximum and $19^{\circ} \mathrm{F}$ minimum. 


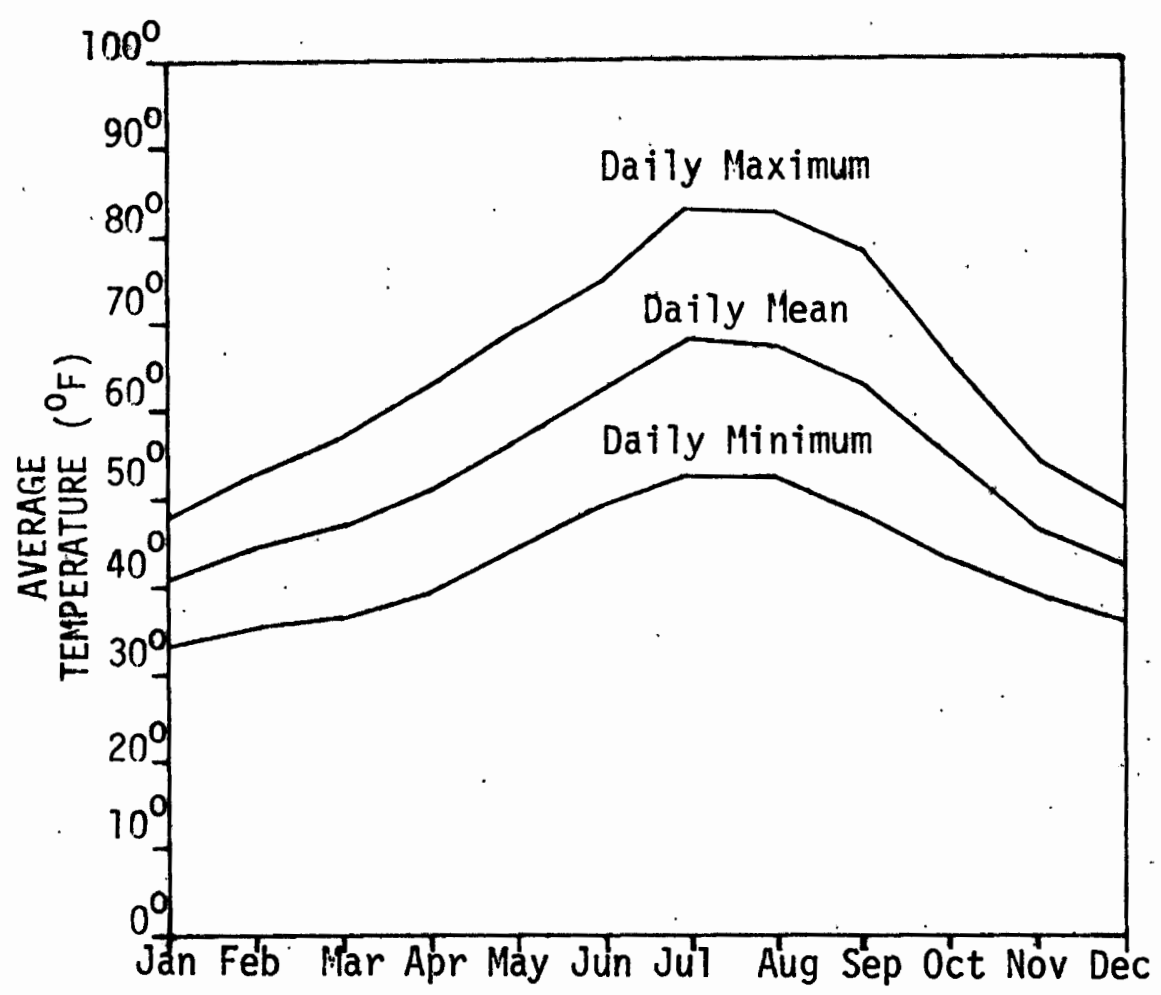

Figure 3. Average monthly temperatures at Roseburg, Douglas County, Oregon.

Source: Environmental Data Service, National Oceanic and Atmospheric Administration, 1974.

\section{HISTORY}

With the influx of settlers into Oregon in the 1840's, Americans began to explore the region, and with the discovery of gold in California and southern Oregon, traffic through the Central Umpqua Valley increased as provisions and supplies moved from the willamette Valley and Scottsburg, the head of navigation on the Umpqua River, to the mining communities. The City of Roseburg, originally platted as Deer Creek, became a major stopping-off place on the journey between California and the Willamette Valley. In 1872 the Oregon \& California 
Railroad reached the county and in 1887 the line over the $K 1$ amath Mountains was finished, placing Roseburg on the only through rail route between Oregon and California.

Eventually the rich alluvial soil and good grazing lands attracted a large number of settlers and small towns began appearing along the main north-south transportation route. Most of these communities exist today, although the interstate highway system, and the main rail line which parallels it, bypass them.

The timber resource base of Douglas County has been utilized since pioneer times. Saw mills cut lumber for early construction and lumber was exported from the mouth of the Umpqua River by sailing vessels. : After the arrival of the railroad, lumber was exported by rail, but there were still vast amounts of virgin timber stands untouched until after World War II, when a frantic national demand for housing stimulated an expansion of the rumber and wood products industry. This expansion continued for two decades until overcutting on private timberlands became apparent, and an era of consolidation was ushered in with "sustained-yield" and "multiple-use" concepts making themselves felt on public timber lands. Utilization of the timber resource base has been an important factor in the historic growth of Douglas County, and future growth in the region will continue to be dependent upon employment in this economic sector.

\section{POPULATION}

The first census conducted after the present boundaries of Douglas County were drawn in 1863 placed the population at 6,066 persons 
in 1870 (Douglas County Planning Department, 1972). Seventy years later, the 1940 census indicated a total of 25,728 persons. The increase of 19,662 persons represented an average annual gain of only 280 persons per year, or about 4.6 percent.

The demand for lumber as a construction material during World War II and the national demand for housing and other consumer goods after the war had immediate effect on Douglas County's population as reflected in Figure 4. The population more than doubled from 1940 to 1950, an increase of 112 percent during the decade. The period 1950 to 1970 saw a considerable decline in the rate of growth for the county, a) though 17,194 persons or 31.5 percent were added to the census rolls. This period experienced a leveling-off of employment in the lumber and wood products industry, and growth in the service-oriented industries within the county. According to the June 1975 estimates by the State Center for Population Research and Census, the population for Douglas County was 80,400 persons, a gain of 8,657 , or an average annual increase of 2.4 percent since 1970 .

The growth of incorporated cities in Douglas County since 1900 is shown in Table I. This table also illustrates the accelerated national trend toward urbanization beginning in the 1940-1950 decade. Urban attractions for the rural population have been such services as water, sewer and transportation facilities, and greater opportunities for employment. In turn, these urban services and the availability of a large labor force have provided the impetus for the location of new large integrated mills in or near county urban areas (Figure 5). 


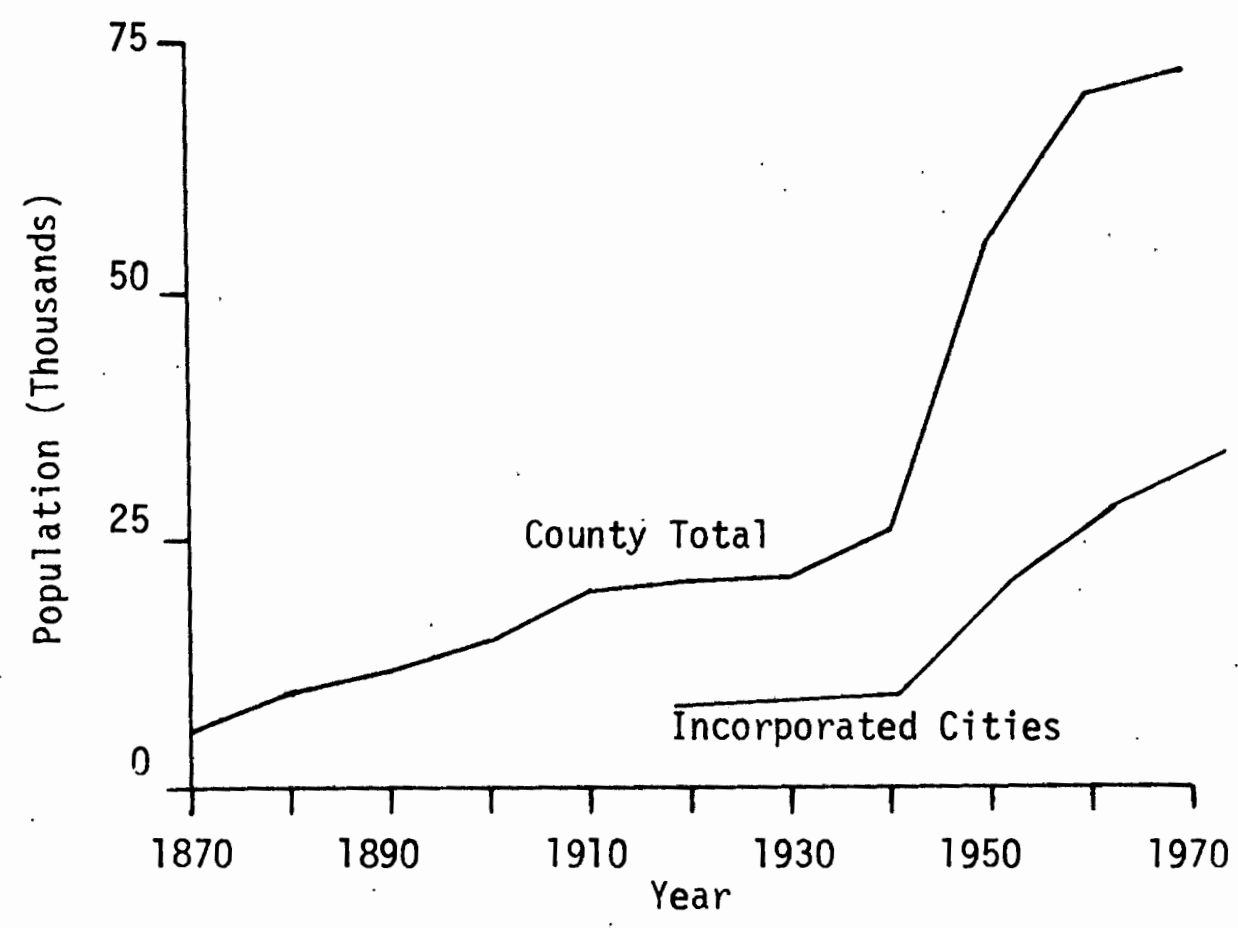

Figure 4. Population growth by decade for Douglas County, Oregon, 1870-1970.

Source: Correspondence with Oregon State Center for Population Research and Census, Portland State University, January 1976.

TABLE I

GROWTH OF CITIES IN DOUGLAS COUNTY, OREGON 1900-1970

\begin{tabular}{|c|c|c|c|c|c|c|c|c|}
\hline ity & 7900 & 1910 & 1920 & 1930 & 1940 & 1950 & 1960 & 1970 \\
\hline any & & 9 & 156 & 67 & 255 & 11 & , 089 & \\
\hline a & 193 & 335 & 607 & 497 & 597 & , 150 & 052 & 4 \\
\hline & - & $-\cdots$ & $\ldots$ & $-\cdots$ & $\cdots$ & & & \\
\hline & $\cdots$ & 646 & 548 & 516 & 557 & 87 & 748 & 10 \\
\hline reek & 189 & 42 & 385 & 401 & 441 & 1,781 & 2,231 & 2 \\
\hline$a k$ & 368 & 467 & & 427 & 367 & 829 & 856 & 1,0 \\
\hline e & & $\cdots$ & 850 & 1,178 & 1,421 & 2,288 & 2,998 & 4,039 \\
\hline$i d d$ & 131 & 187 & 268 & 195 & 195 & 274 & 992 & 1,042 \\
\hline & 690 &, 738 &, 381 & 360 & 4,924 & 300 & 11,467 & in \\
\hline & & $\cdots$ & 515 & 457 & In & 2230 & 2,452 & \\
\hline & & --- & $\cdots$ & $-\ldots$ & $\ldots$ & $\cdots$ & 2,395 & 68 \\
\hline & $-\ldots$ & 233 & 232 & 252 & 277 & 626 & 69 & \\
\hline
\end{tabular}

Source: Oregon State Center for Population Research and Census, Portland State University, March, 1976. 


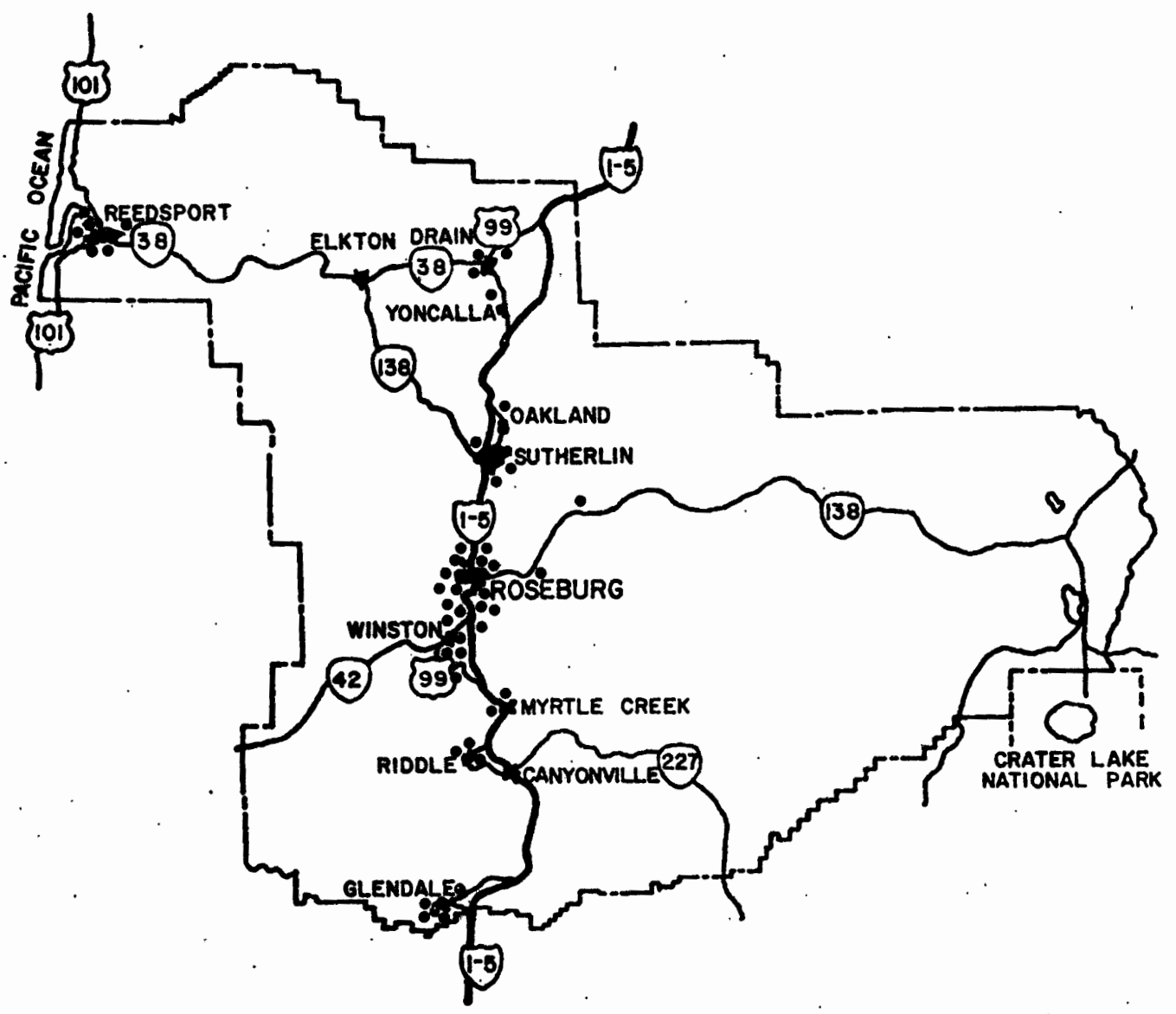

Figure 5. Wood products manufacturing firms, 1970.

Source: State of Oregon Department of Economic Development, Directory of Oregon Manufacturers 1976-1977, (Portland, Oregon, January 1976).

\section{EMPLOYMENT}

As evidenced by Figure 6, employment trends in Douglas County reflect the cyclical nature of the dominant lumber and wood products sector of the local economy with peaks and troughs prevailing. The upward trend in total employment has been achieved by a tremendous growth in the non-manufacturing sectors, discussed later in this section. 


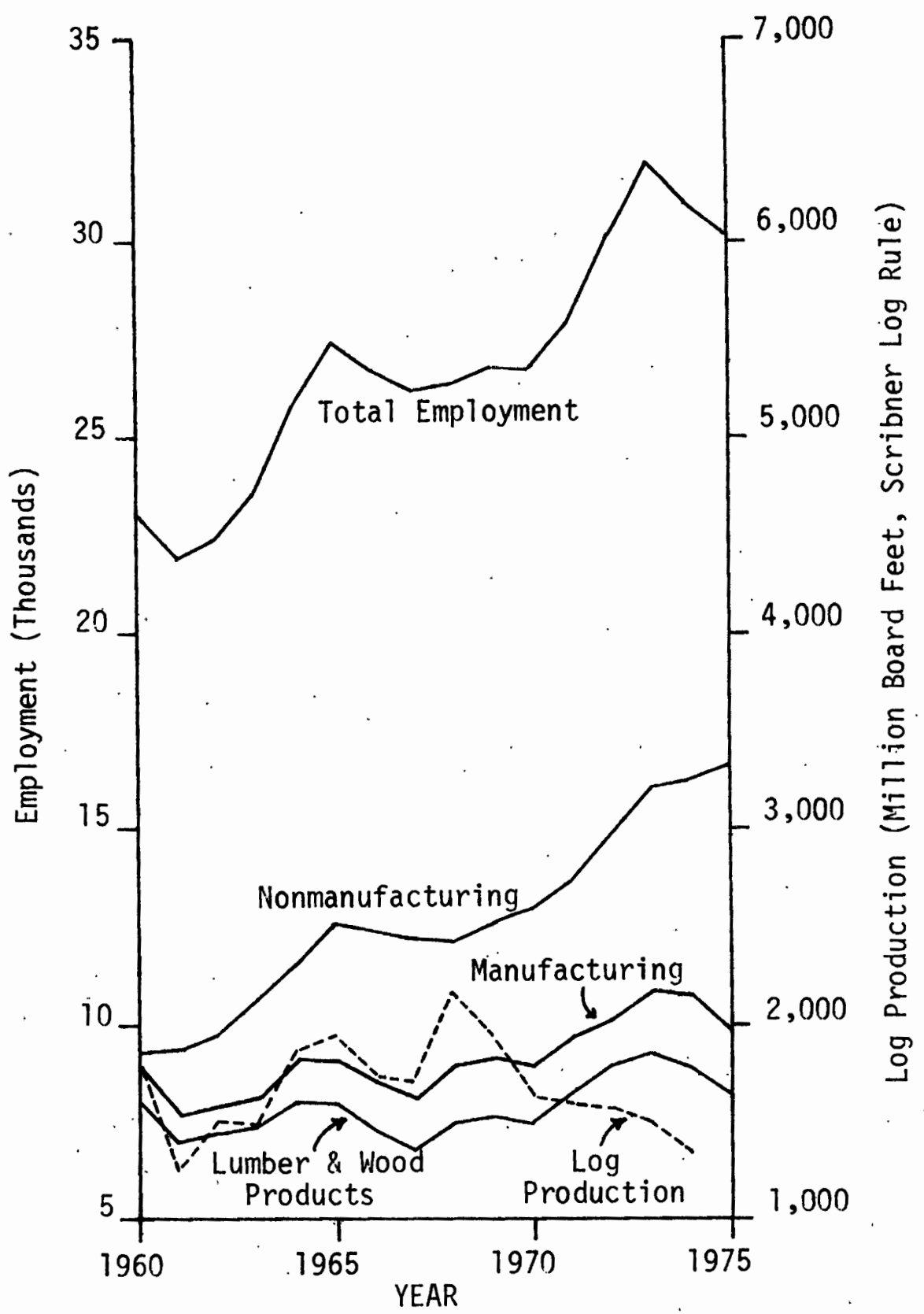

Figure 6. Employment and log production in Douglas County, Oregon, 1960-1975.

Source: C.C.D. Economic Improvement Association, Douglas County Population and Employment Projections, 1975-1990, (Roseburg, Oregon, March 1976): table IV; Brian R. WalT, Log Production in Washington and Oregon: An Historical Perspective,(Portland, Oregon, 1972): tab7es 44 through 54, pp. 79-89; Forest Survey Project, Oregon Timber Harvest (1971 through 1974), (Pacific Northwest Forest and Range Experiment Station, Portland, Oregon, published annuaily). 
Manufacturing

Douglas County's manufacturing employment is dominated by the Tumber and wood products industry that composes 83.2 percent of total manufacturing employment. Logging employed approximately 1,800 persons during 1975, sawmills, 2,250 and veneer and plywood mills and others, 4,250 employees. Of the remaining 16.8 percent of manufacturing employment, 4.5 percent is attributable to primary metals, 2.1 percent to food products and 11.1 percent to other, assorted durable and nondurable manufacturing including pulp and paper, printing and machinery.

Since the forest products industry is the major manufacturing employer, Figure 6 does not reflect the significant gains made in a few of the other manufacturing sectors. Manufacturing employment has decreased from 38.6 percent of total employment in 1960 to 32.9 percent in 1975 due primarily to the faster growth rate of employment in the nonmanufacturing sectors (CCDEIA, 1976a). Average annual growth in the manufacturing sector from 1960 to 1975 approached 0.8 percent, a very modest increase as employment rose from 8,900 to 9,950 persons.

As evidenced by Figure 6, more complete utilization of the forest resource, primarily utilization of wood chips for particleboard and pulp, has enabled the forest products industry to maintain employment in the face of increased productivity and decreased timber harvest (Umpqua Regional Council of Governments, 1976). Due to the economic recession in 1974 and 1975, the total growth of the lumber and wood products industry since 1960 was 150 persons, or approximately 0.1 percent average annual increase. 
Nonmanufacturing

Employment in the nonmanufacturing sectors of Douglas County's economy has been increasing dramatically since 1960 with an average annual growth rate of 5.6 percent, as this segment increased from 9,270 to 17,090 persons in 1975 (CCDEIA, 1976a). This 1ong-term growth occurred as Roseburg became established as a major market center for southwest Oregon, with additional shopping opportunities and a wider range of service establishments. Additionally, federal, state and local governmental agencies have. been established, or have expanded in the county. 


\section{CHAPTER III}

\section{THE ECONOMIC BASE OF, DOUGLAS COUNTY}

The purpose of this chapter is to determine the economic base of Douglas County as presented by two previous input-output studies of the county's economy. Input-output analysis can measure the dependency of Douglas County upon the Tumber and wood products industry. Further, it can hopefully provide reliable multipliers to estimate the impact of a reduction in employment in the forest products industry upon total employment in the county.

Economic base theory maintains that the growth and existence of a regional economy depends on the growth and existence of local industries that provide goods and services for markets outside of the region (Tiebout, 1962). Those industries that export their products provide "basic" income and employment in the region. All other sectors of the economy depend on the "basic", or "export" income and employment, and because of their dependent nature are titled "non-basic" or "service" industries.

Studies by the U.S. Forest Service have used input-output tables of sales developed for Douglas County to determine the effects of various management policies upon local economies (Youmans et al., 1973; Darr and Fight, 1974). Analyzing the dollar flow of sales by industry can lead to a determination of exactly which industries are basic within the region. If total export sales minus total import purchases for 
comparable products results in a net export figure, then the industry is part of the "basic" economy of the area. Table II presents the basic industries of Douglas County in order of value of net exports as computed from the input-output tables compiled by Darr and Fight (1974).

\section{TABLE II}

BASIC INDUSTRIES OF DOUGLAS COUNTY, OREGON, 1970

\section{Sector}

1. Plywood and Veneer Mills

2. Sawmilis

3. State and Federal Government

4. Tourists

5. Non-forest Products Manufacturing

6. Timber Harvesting and Hauling

7. Pulp, Paper and Particleboard Piants

8. U.S. Forest Service Timber Sales

9. Livestock

10. Horticul ture

11. Bureau of Land Management Timber Sales Tota1 Net Exports
VaTue of Net Exports

$\$ 76,483,146$

$39,495,939$

$32,077,370$

$18,851,170$

$11,717,424$

$9,279,674$

$8,725,863$

$4,875,004$

$3,945,674$

$2,976,971$

$1,475,114$

$\$ 209,842,809$

Source: David R. Darr and Roger D. Fight, Douglas County, Oregon: Potential Economic Impacts of a Changing Timber Resource Base, PNW-169, (Pacific Northwest Forest and Range Experiment Station, Portiand, Oregon, 1974): p.5, table 1.

It is readily apparent that the lumber and wood products industries are the predominant basic industries in Douglas County. The four forest processing sectors total $\$ 133,924,612$ worth of net exports, or 
approximately 41.7 percent of the total exports of the county and 63.8 percent of exports by basic industries in the county. All other sectors of the local economy not represented in Table II are net importers.

Darr and Fight (1974) determined that the Douglas County economy is 68.7 percent dependent upon the Tumber and wood products industry. This degree of dependency was derived by multiplying the direct and indirect linkages for each of the lumber and wood products industries by the final demand for each industry from other sectors of the local economy, and summing to obtain the total dependency. The linkages represent the fractional amount of sales accorded to other sectors of the economy per dollar of export sales in the lumber and wood products industries.

The degree of dependency upon timber-based employment shown by Douglas County is also significant in comparison to other areas of western Oregon. Table III utitizes data for selected economic areas in western Oregon as contained in a study by Maki and Schweitzer (1973) for the entire Douglas-fir region of Oregon and Washington (Figure 7). Upon analysis of Table III, it is readily apparent that the county is extremely dependent upon its timber resources for employment opportunities. The complete data from the source cited in the table indicate that a reduction in timber harvest would have a greater adverse affect upon Douglas County than any other area in Oregon and Washington. 
TABLE III

DEPENDENCY UPON TIMBER-BASED EMPLOYMENT FOR SELECTED ECONOMIC AREAS IN WESTERN OREGON, 1970

\begin{tabular}{llc}
\hline Economic Area & \multicolumn{1}{c}{$\begin{array}{c}\text { Percentage of Export } \\
\text { Counties }\end{array}$} & $\begin{array}{c}\text { Employment } \\
\text { industries }\end{array}$ \\
\hline Portland & $\begin{array}{l}\text { Columbia, Clackamas, } \\
\text { Multnomah, Yamhill, } \\
\text { Hood River }\end{array}$ \\
Salem & $\begin{array}{l}\text { Marion, Polk } \\
\text { Astoria }\end{array}$ & Clatsop, Tillamook \\
Medford & Jackson, Josephine & 23 \\
Corvallis & Linn, Benton, Lincoln & 53 \\
Eugene & Lane & 73 \\
Coos Bay & Coos, Curry & 78 \\
Roseburg & Douglas & 91 \\
\hline
\end{tabular}

Source: Wilbur R. Maki and Dennis L. Schweitzer, Importance of Timber-Based Employment to the Douglas-fir Region, 1959 to 1971 , PNW-196, (Pacific Northwest Forest and Range Experiment Station, Portland, Oregon, June 1973): p.11, table 2.

Youmans et al. (1973) also constructed an input-output coefficient matrix for the county from dollar flow data compiled for their study, and generated output multipliers for each sector of the county's economy. Each multiplier indicates the number of dollars of total production in the local economy generated by one dollar of demand in that sector. The actual multipliers derived for the forest products industries are presented in Table IV. 


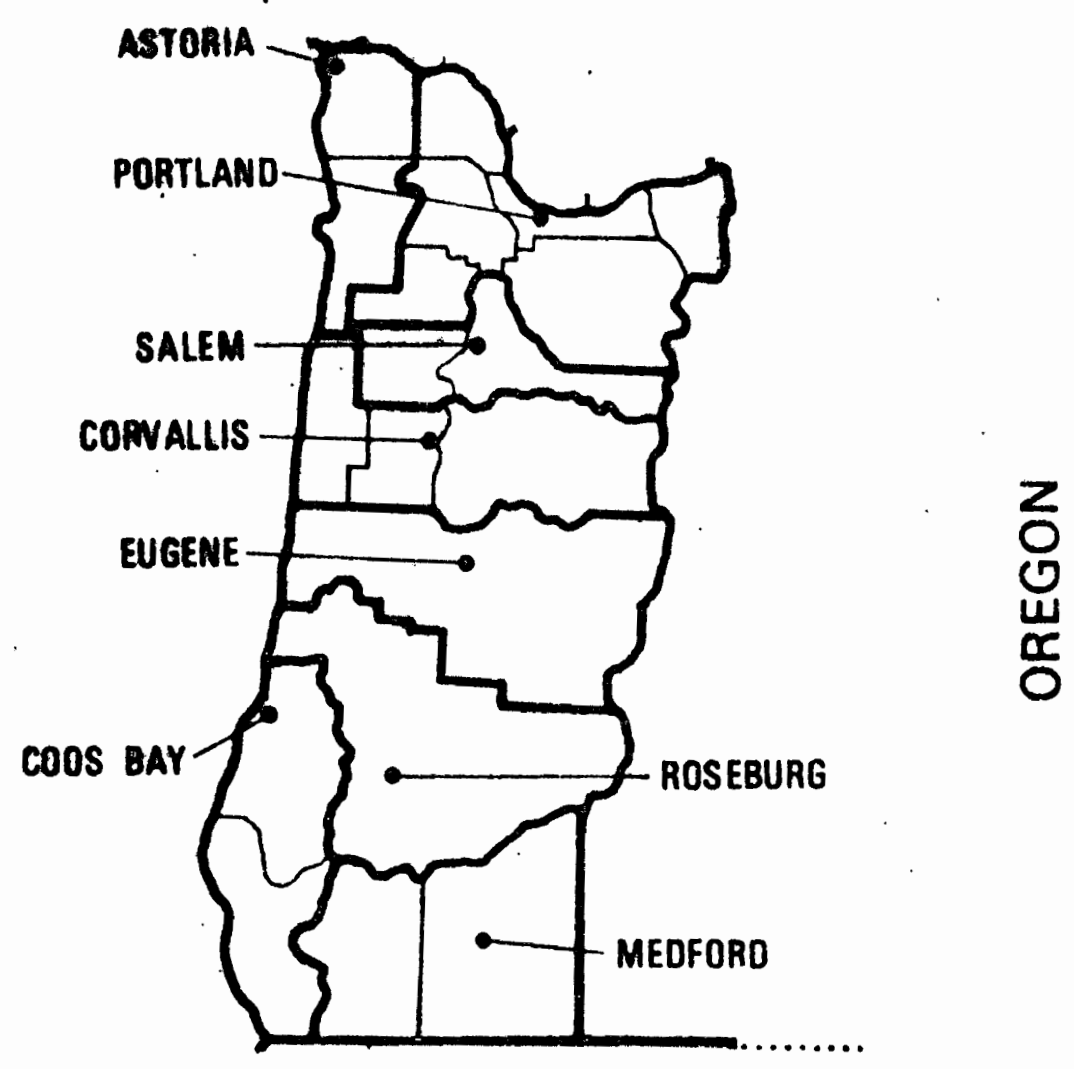

Figure 7. Economic areas in the Douglas-fir region of Oregon.

Source: Wilbur R. Maki and Dennis L. Schweitzer, Importance of Timber-Based Employment to the Douglas-fir Region, 1959 to 1971, PNW-196, (Pacific Northwest Forest and Range Experiment Station, Portland, Oregon, June 1973): p. 5, figure 2.

The multipliers for timber harvesting and hauling, sawmills, and plywood and veneer mills are relatively high in comparison to the other industrial sectors of Douglas County, which have an average multipijer of 2.42 , because historically the county has been a timber-oriented economy and the necessary supplies and services for these industries are available. On the other hand, pulp and paper mills rely heavily on outside suppliers for much of their special needs, which results in a lower multiplier (Youmans et al., 1973). 
TABLE IV

FOREST INDUSTRY MULTIPLIERS FOR DOUGLAS COUNTY, OREGON'

Sector

Timber Harvesting and Hauting

Sawmills

Plywood and Veneer Mitls

Pulp, Paper and Particleboard Plants

Industries Other Than Above

A11 Industries in Douglas County
Multiplier

2.49

3.09

2.39

1.54

2.42

2.53

Source: Russe11 C. Youmans, David R. Darr, Roger Fight, and Dennis L. Schweitzer, Douglas County, Oregon: Structure of a Timber County Economy, (AgriculturaT Experiment Station, Oregon State University, Corvallis, Oregon, December 1973):p. 20, table 6.

A comparison of Youmans' study with data compiled for 375 Appalachian counties (Table V) indicates that Douglas County has a larger average multiplier than might be expected of a county with a Tabor force of 30,000 persons. The average multiplier for Douglas County as indicated in Table $V$ was 2.53 , which exceeds the probable range of 2.0 to 2.4 for counties with a similar number of persons employed. The probability of an individual county multiplier being included within the range was seventy percent.

One possible explanation for the larger average multiplier for all Douglas County industries has already been discussed, namely the historic orientation to the forest products industry. Another factor may be the geographical size of Douglas County. As the fifth largest 
county in the State of Oregon, the county is considerably larger than many of the counties in Appalachia. Thus, the increased travel time and distance to alternative shopping or supply complexes creates an opportunity for additional businesses to locate within the county.

\section{TABLE V}

AVERAGE MULTIPLIER VALUES AND RANGES BY COUNTY EMPLOYMENT SIZE CLASSES

\begin{tabular}{ccc}
\hline $\begin{array}{c}\text { County Employment } \\
\text { Size Class }\end{array}$ & $\begin{array}{c}\text { Average } \\
\text { Multiplier }\end{array}$ & $\begin{array}{c}\text { Probable } \\
\text { Range }\end{array}$ \\
\hline $1,000-2,999$ & 1.7 & $1.5-1.9$ \\
$3,000-4,999$ & 1.8 & $1.5-2.0$ \\
$5,000-9,999$ & 1.9 & $1.6-2.1$ \\
$10,000-19,999$ & 2.0 & $1.8-2.2$ \\
$20,000-49,999$ & 2.2 & $2.0-2.4$ \\
50,000 and over & 2.2 & $2.0-2.5$ \\
\hline
\end{tabular}

Source: John R. Fernstrom, "Bringing In The Sheaves", (Oregon State University Extension Service, Corval7is, Oregon, 1973): p. 108, table 13.1. 


\section{SELECTED FACTORS AFFECTING FUTURE TIMBER INDUSTRY EMPLOYMENT IN DOUGLAS COUNTY, OREGON}

Historically, the timber industry in Douglas County has been affected by national forces over which it had little control. The national demand for housing, which has had a major impact on the local economy since the late $1940^{\prime} \mathrm{s}$, was influenced by such diverse factors as the Federal Reserve Board's monetary policy, interest rates on mortgages, inflation rates, unemployment rates and a host of other elements. As national demand for wood products begins to exceed national supply, the availability of local timber will become a major limiting factor for local forest products production and employment. This chapter looks at the projected declining timber harvest, and timber. flows between. Douglas County and adjacent counties to analyze the local timber supply. In addition, labor force productivity increases are discussed to determine the future manpower needs of wood products oriented production processes.

As shown in Figure 8, which presents a hypothetical aggregate timber supply and demand function, increased demand for forest products from $D$ to $D^{\prime}$ results in increased supply as the quantity moves from $Q$ to $Q^{\prime}$. As future demand shifts even higher (shown by the second graph in Figure 8 ), the supply curve (S) could be intersected in the inelastic section (which represents maximum output) so that the result will be higher prices without increased supply. The inelastic portion 
of the supply curve could be shifted to a lower position as a result of continued diversion of lands from commercial timber production, or shifted upwards as a result of intensive management and increased utilization.
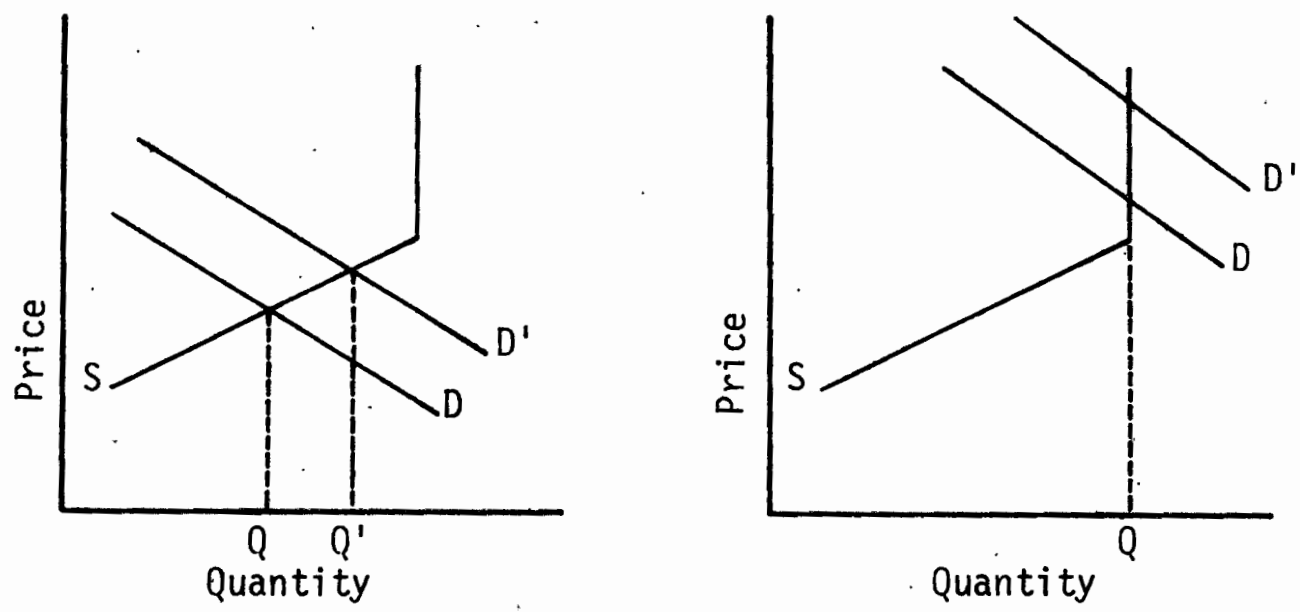

Figure 8. Hypothesized aggregate timber supply and demand.

Source: Richard D. Gustafson, "Regional Employment Impacts of Timber Harvest Changes in Oregon," (Oregon State University, Corvat7is, Oregon, June 1975): p. 3, figure 1.

\section{A DECLINING TIMBER HARVEST}

Employment opportunities in the lumber and wood products industry of Douglas County are dependent upon production levers in local mills, which may be seriously affected if there is a retraction in the quantity of raw materials available. In $1963 \mathrm{Dr}$. Louis Hamill, Professor of Business Administration at the University of Oregon, predicted that the total log supply in Douglas County would fall drastically in the next thirty years. His predictions were based on the assumption that, even with conservative management of private lands, the annual harvest of timber from these lands would decline from the 1960 level of 1.2 billion 


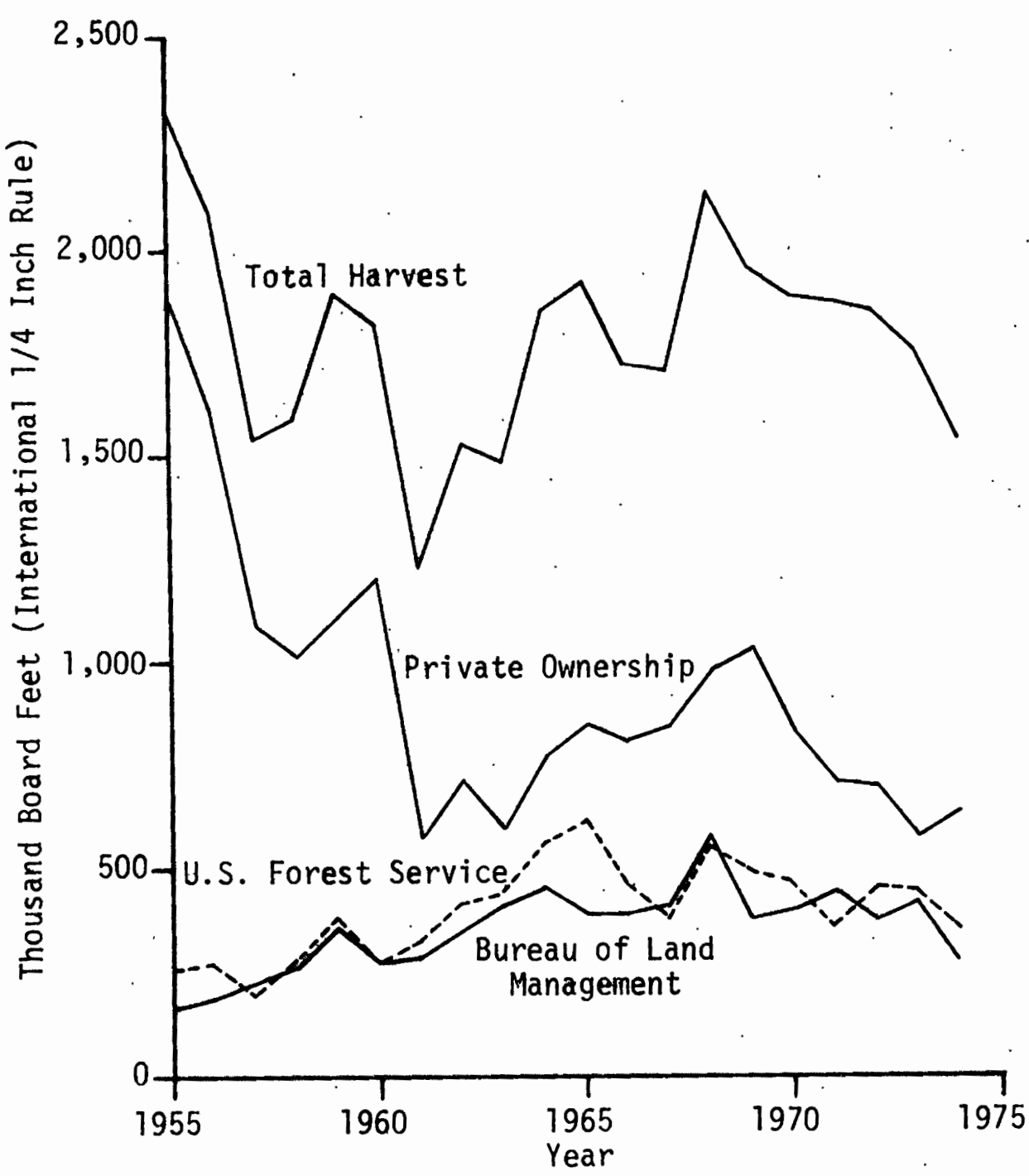

Figure 9. Douglas County timber harvest, 1955-1974

Source: Brian R. Wa11, Log Production in Washington and Oregon: An Historical Perspective, PNW-42, (Pacific Northwest Forest and Range Experiment Station, Portland, Oregon, 1972): pp. 79-89, tables 44 through 54; Forest Survey Project, Oregon Timber Harvest (1971 through 1974), Pacific Northwest Forest and Range Experiment Station, Portland, Oregon, published annually).

forest lands in western Oregon. The reduction to 100 million board feet on private lands projected by Hamill (see page 32) for Douglas County in 1990 would represent 16.9 percent of the 1974 harvest from 
that county.

Although the U.S. Forest Service report (Gedney et al., 1975) was usefut in verifying the trends in timber supply throughout the Pacific Coast states, it has marginal use to planners and local government officials because it does not address itself to specific locations. Such data became available in January of 1976 in a publication entitled Timber for Oregon's Tomorrow (Beuter et a1., 1976). This work analyzed ten different timbersheds within the State of Oregon. A timbershed is basically a lumber oriented functional economic area in which at least 67 percent of the timber harvested in the unit was consumed, or processed therein. The conclusion reached for Douglas County was that the current total timber harvest could be maintained through 1995, after which time a decline of about 22 percent would occur, given continuation of present policies and programs. Harvesting timber at the current levels to that date would result in vast amounts of old growth timber on both public and private lands being cut. As a result there would be a decline in harvestable timber.

The publication presented alternative futures of timber harvest throughout western Oregon. Table VI indicates the projected deviation from current harvest levels for the seven timbersheds in western Oregon shown in Figure 7. Even given the most optimistic assessment of changes in timber management policy over the next 30 years, Douglas County will encounter a declining supply of its timber resources from present levels. Attainment of the maximum intensive forest management level would require that all owner groups achieve their highest possible harvest in light of advanced silviculture methods. In view of budgetary constraints 
encountered by the public sector and smaller private landowners, it seems highly unlikely that this goal could be attained. One notes from the data, however, that there is but minimal gain in most instances in increasing forest management practices from "minimum" to "maximum".

Conversely, the figures indicated as resulting from a continuation of present policies and programs, do not seem to accurately reflect the on-going changes in forest management practices. The major timber industry firms are leaders in advancing and utilizing silvicultura 1 methods. At the same time, additional funding by Congress has assured the U.S. Forest Service of adequate monies for planting areas clearcut in previous years. It seems that the future harvest of timber from Douglas County will fall between these extremes, though not necessarily at the minimum intensive management forecast level.

\section{TIMBER FLOWS OF DOUGLAS COUNTY}

One of the major reasons why it is difficult to accurately forecast the impact that a decline in the timber harvest will have upon Douglas County is that a significant portion of the harvest is exported to other counties (Austin, 1969; Manock et al., 1970, Schuldt et a1, 1974). Only one study (Austin, 1969) effectively deals with timber flows on a county basis for the State of Oregon, but the data are ten years 01d. Two other studies (Manock et al., 1970; Schuldt et al., 1974) provide only partial information on flow characteristics, since the main emphasis of these particular reports is on mill characteristics. Selected data from the three studies appear in Table VII. 
TABLE VI

TIMBER PRODUCTION BY TIMBERSHED FOR THREE TIMBER FLOW PROJECTIONS SHOWN AS RATIOS TO 1968-1973 ANNUAL AVERAGE HARVEST

\begin{tabular}{|c|c|c|c|c|}
\hline Timbershed & Decade & $\begin{array}{l}\text { Current } \\
\text { Policies } \\
\end{array}$ & $\begin{array}{l}\text { Minimum } \\
\text { Intensive } \\
\text { Forest } \\
\text { Management } \\
\text { Forecast } \\
\end{array}$ & $\begin{array}{l}\text { Maximum } \\
\text { Intensive } \\
\text { Forest } \\
\text { Management } \\
\text { Forecast }\end{array}$ \\
\hline North Coast & $\begin{array}{l}1975-1985 \\
1985-1995 \\
1995-2005\end{array}$ & $\begin{array}{l}\text { Current } \\
1.00 \\
1.00\end{array}$ & $\begin{array}{l}1.20 \\
1.19 \\
1.24\end{array}$ & $\begin{array}{l}1.25 \\
1.26 \\
1.33\end{array}$ \\
\hline $\begin{array}{l}\text { North } \\
\text { Wi } 1 \text { lamette } \\
\text { Vall ey }\end{array}$ & $\begin{array}{l}1975-1985 \\
1985-1995 \\
1995-2005\end{array}$ & $\begin{array}{l}\text { Current } \\
0.79 \\
0.69\end{array}$ & $\begin{array}{l}1.27 \\
1.19 \\
1.17\end{array}$ & $\begin{array}{l}1.33 \\
1.26 \\
1.26\end{array}$ \\
\hline $\begin{array}{l}\text { Mid-Willamette } \\
\text { Valley }\end{array}$ & $\begin{array}{l}1975-1985 \\
1985-1995 \\
1995-2005\end{array}$ & $\begin{array}{l}\text { Current } \\
0.99 \\
0.87\end{array}$ & $\begin{array}{l}0.97 \\
0.92 \\
0.91\end{array}$ & $\begin{array}{l}1.00 \\
0.96 \\
0.96\end{array}$ \\
\hline Eugene & $\begin{array}{l}1975-1985 \\
1985-1995 \\
1995-2005\end{array}$ & $\begin{array}{l}\text { Current } \\
0.73 \\
0.59\end{array}$ & $\begin{array}{l}0.86 \\
0.83 \\
0.84\end{array}$ & $\begin{array}{l}0.88 \\
0.86 \\
0.87\end{array}$ \\
\hline Roseburg & $\begin{array}{l}1975-1985 \\
1985-1995 \\
1995-2005\end{array}$ & $\begin{array}{l}\text { Current } \\
1.00 \\
0.78\end{array}$ & $\begin{array}{l}0.96 \\
0.92 \\
0.92\end{array}$ & $\begin{array}{l}0.99 \\
0.96 \\
0.97\end{array}$ \\
\hline South Coast & $\begin{array}{l}1975-1985 \\
1985-1995 \\
1995-2005\end{array}$ & $\begin{array}{l}\text { Current } \\
1.00 \\
0.64\end{array}$ & $\begin{array}{l}1.02 \\
1.00 \\
1.02\end{array}$ & $\begin{array}{l}1.04 \\
1.03 \\
1.06\end{array}$ \\
\hline Medford & $\begin{array}{l}1975-1985 \\
1985-1995 \\
1995-2005\end{array}$ & $\begin{array}{l}\text { Current } \\
1.00 \\
0.98\end{array}$ & $\begin{array}{l}1.11 \\
1.03 \\
1.03\end{array}$ & $\begin{array}{l}1.14 \\
1.06 \\
1.08\end{array}$ \\
\hline Western Oregon & $\begin{array}{l}1975-1985 \\
1985-1995 \\
1995-2005\end{array}$ & $\begin{array}{l}\text { Current } \\
0.93 \\
0.78\end{array}$ & $\begin{array}{l}1.03 \\
1.00 \\
1.02\end{array}$ & $\begin{array}{l}1.07 \\
1.04 \\
1.07\end{array}$ \\
\hline
\end{tabular}

Source: John H. Beuter, K. Norman Johnson, and H. Lynn Scheurmann, Timber for Oregon's Tomorrow, (Forest Research Laboratory, Oregon State University, Corvall is, Oregon, January 1976): p. 109, table A16. 
TABLE VII

NET EXPORTS* BY OWNER CLASS FROM DOUGLAS COUNTY, OREGON

\begin{tabular}{rrrrrr}
\hline & $\begin{array}{l}\text { Nationa } \\
\text { Forests }\end{array}$ & $\begin{array}{l}\text { Bureau } \\
\text { Of Land } \\
\text { Management }\end{array}$ & State & Private & Total \\
\hline 1966 & 41,588 & 83,080 & 27,798 & 332,501 & 484,967 \\
1968 & 152,981 & 149,983 & $-1,163$ & 408,996 & 720,336 \\
1972 & 87,128 & $-119,503$ & $-2,834$ & 417,338 & 380,125 \\
\hline
\end{tabular}

* Thousand Board Feet, Scribner Log Rule

Note: Negative numbers represent net imports into Douglas County from these owner classes.

Source: John W. Austin, Timber Flows and Utilization Patterns in the Douglas-fir Region, 1966, PNW-89, (Pacific Northwest Forest and Range Experiment Station, Portiand, Oregon, 1969): p. 45, Table 9; Eugene R. Manock, Grover A. Choate and Donald R. Gedney, Oregon Timber Industries, 1968 Wood Consumption and Mil1 Characteristics, (State of Oregon, Department of Forestry, SaTem, Oregon, December 1970): pp. 48-49, TabTe 4; John P. Schult and James 0. Howard, Oregon Forest Industries 1972 Wood Consumption and Mil1 Characteristics, (Oregon State University Extension Service, Corvallis, Oregon, December 1974): pp. 34-35, Table 4.

It is readily apparent from the table that, in all three years, exports from private lands were the primary source of exports from Douglas County. Furthermore, these same sources indicate that Lane County is the largest recipient of these exports with Coos county second.

Weyerhaeuser Company is the largest private land owner in Douglas County with approximately 165,00 acres, or 21.7 percent of forest industry lands (News-Review, February 5, 1977). This international 
manufacturing firm has no processing plants within Douglas County. Rather it has major manufacturing complexes at Springfieid and Cottage Grove, in Lane County, and Coos Bay in Coos, County (see Figure 10). It seems safe to assume that a large portion of the private timber flows from Douglas County are influenced by this company and the location of $i$ ts processing plants. In addition, Longview Fibre Company, GeorgiaPacific and Bohemia, Inc. are other private owners of county forest lands with processing plants outside of the county.

Mr. Ernie Niemi of Alpha Research, a consultant to Douglas Timber Operators, stated in a personal conversation with the author (26 August 1976) that only one local firm owns over 100,000 acres of the commercial forest lands in the county. Most of the other wood-processing plants in the county are dependent upon public forest lands for their supply of logs.

It is difficult to ascertain the trends in exports from national forest lands as indicated by Table VII, al though 1972 demonstrated an increase over 1966. The distance of the Umpqua National Forest from other manufacturing complexes in adjacent counties may preserve this forest as a major source of supply for Douglas County mills. Conversely, the same distance factor may impede local firms from acquiring additional logs from other national forests (see Figure 10).

The drastic change in the amount of timber consumed from the Bureau of Land Management reserves is indicative of the growing timber shortage in Douglas County. The BLM lands represent the most accessible sources of timber for Douglas County mills, extending as they do in all directions from the Central Umpqua Valley. Partially for this reason the BLM lands accounted for 97.7 percent of the imports into the county. 


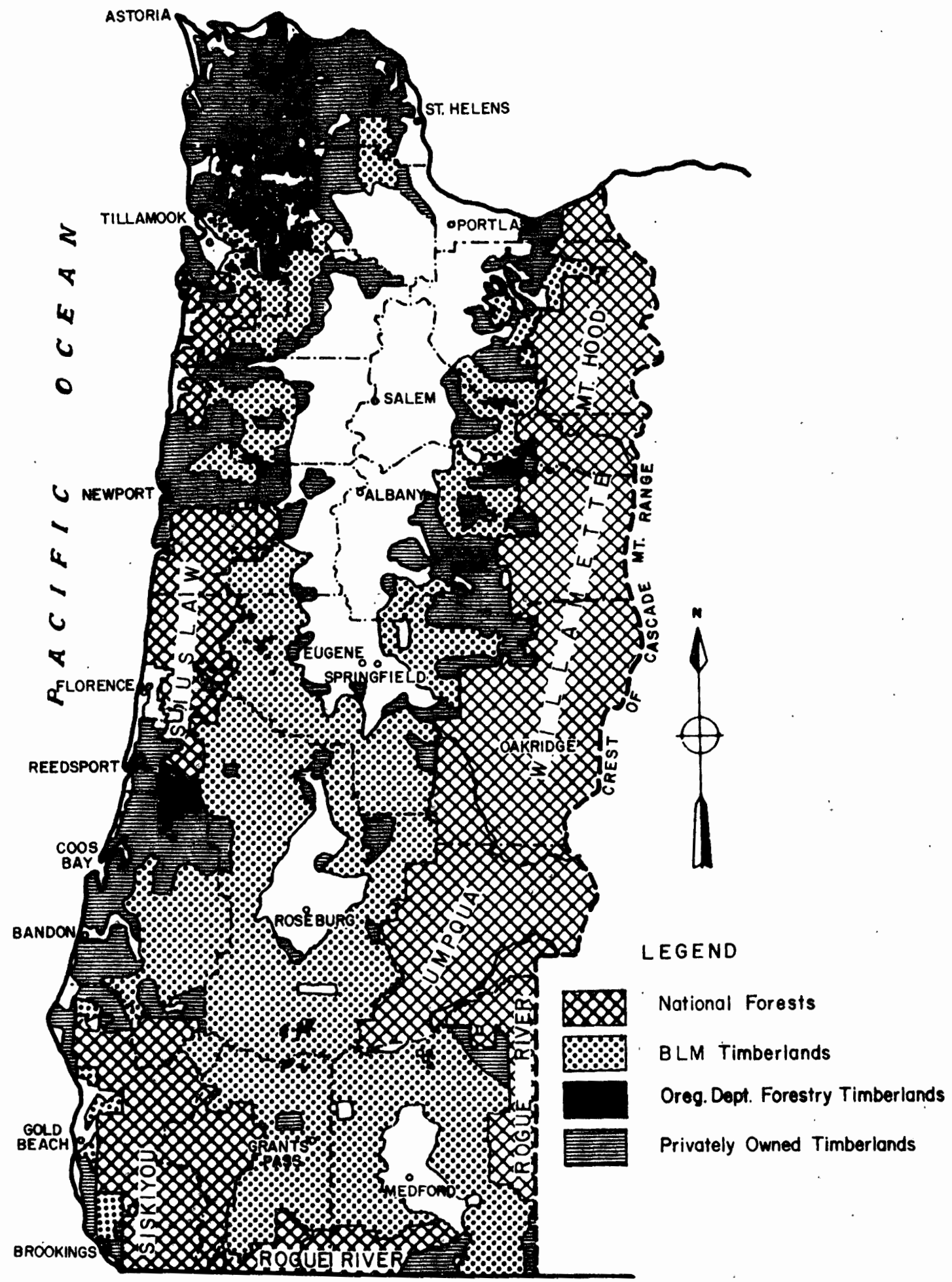

Figure 10. Timberlands in western Oregon.

Source: Murray, Thomas J. and Associates, Oregon's Timber Resource, (Portland, Oregon, September 1966): p. viii, plate 1. 
State of Oregon commercial timber lands are not significant enough to take up the slack in the timber shortage, al though consumption from these lands did increase over the 1966-1972 time period. The imports are probably derived from Elliott State Forest in adjacent Coos County (see Figure 10): Lastly, large blocks of private timber are dedicated to company mills located outside of Douglas County. As the major firms continue to buy commercial timberlands from other private owners in the county, exports from the private owner class may be expected to increase.

\section{PRODUCTIVITY}

Increased productivity per employee due to mechanization and automation has played an important role in determining the employment levels of the lumber and wood products industry. The Oregon State Employment Division estimated the productivity gains in the various sectors of the forest products industry for the State of Oregon as shown in Table VIII.

A recent U.S. Forest Service study developed the linear regression equations shown in Figure 11 to predict future productivity levels in western Oregon to the year 2000 (Wall and Oswald, 1975). Using 1950 to 1970 as a base period resulted in forecasts that predict a significant decline in the labor requirements of the forest products industries. The logging sector is expected to decline from 1.426 employees for every million board feet harvested in 1975 to 1.106 in the year 2000. In 1975 there were 3.11 employees required in sawmills and planing mills for every million board feet of lumber processed, and in 2000 it is projected to be 1.19. The equation developed for veneer and plywood mills predicts 
a level of 2.22 employees per million board feet in 2000, a considerable reduction from the 1975 estimate of 5.75 .

TABLE VIII

PERCENT CHANGE IN PRODUCTIVITY PER EMPLOYEE 1960-1965

Sector

Percentage

Logging

10.3

Sawmills

20.9

Veneer and Plywood

19.3

Source: Oregon State Employment Service, The Effects of Technological Change on Employment in the Lumber Industry, (SaTem, Oregon, 1968).

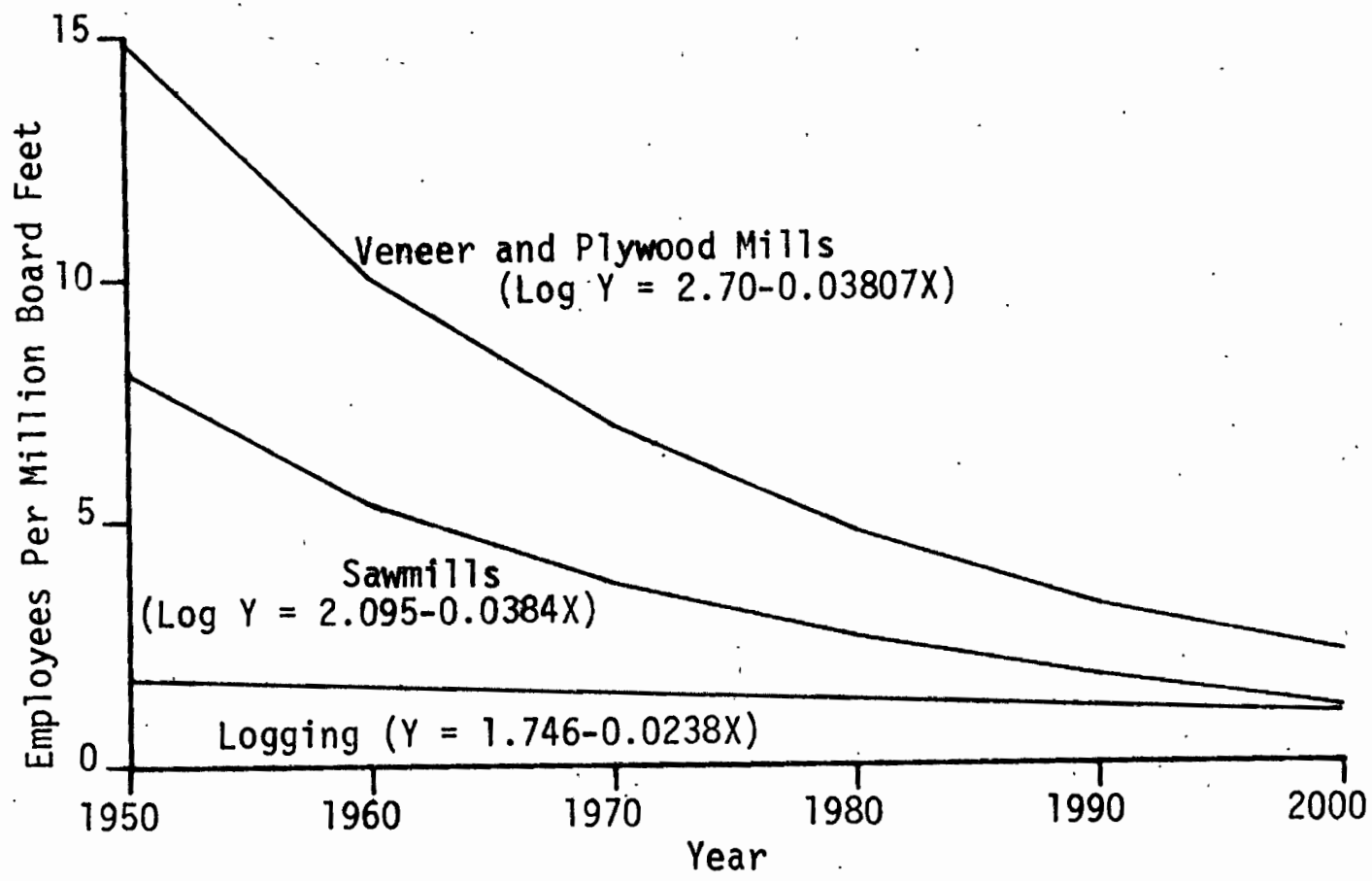

Figure 11. Estimated productivity leve1s in the forest products industries of western Oregon, 1950-2000.

Source: Brian R. Wall and Daniel D. Oswald, A Technique and Relationships for Projections of Employment in the Pacific Coast Forest Products Industries, PNW-189, (Pacific Northwest Forest and Range Experiment Station, Portland, Oregon, 1975). 


\section{CHAPTER $V$}

\section{FUTURE FOREST PRODUCTS EMPLOYMENT}

The simplest method of predicting the future is to assume that it will maintain the same pattern as in the past. Recent reports by the Coos, Curry, Douglas Economic Improvement Association (1976a) utilized such assumptions in a linear regression analysis of time and employment in Douglas County to the year 1990. The equation developed for the lumber and wood products industry in the report was $E=7,457+$ 46.6176T, where $E$ represents employment and $T$ represents time in number of years (Figure 12). The result was an employment level of 8,995 in 1990, compared with an average for 1970 through 1975 of 8,740 persons. Therefore, the linear regression equation essentialiy represents stable employment levels for the next 15 years. However, the coefficient of determination $\left(r^{2}\right)$ for this equation was only .116 , indicating a weak relationship between time and employment in the lumber and wood products industry. This would seem to be an accurate statement in light of the effect that national forces have had upon the demand for forest products which was reflected in timber harvest levels (see page 24), and productivity increases which are not steady rates of increase, but rather leaps, as new methods and machinery are developed and implemented into the production process. 


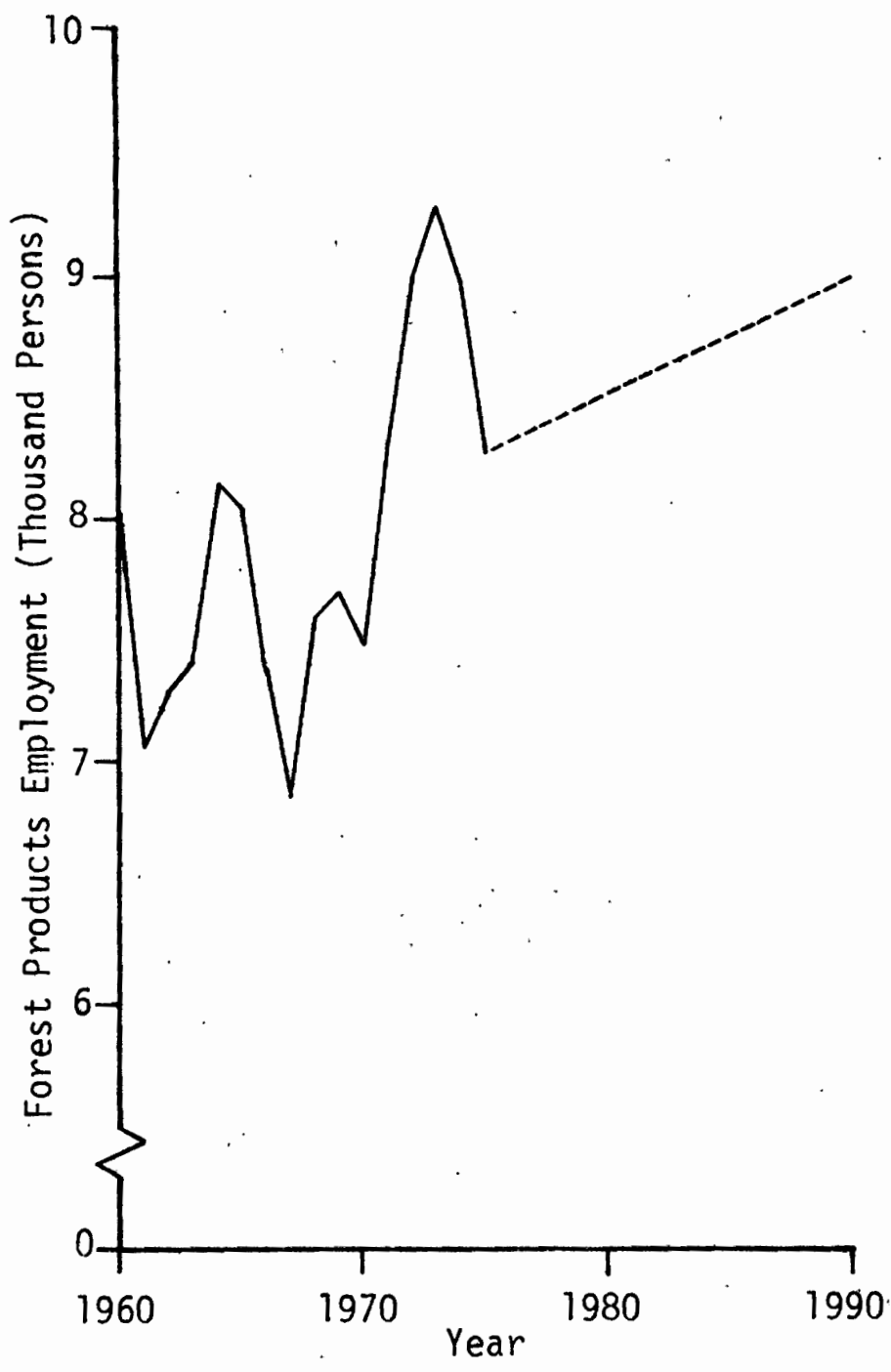

Figure 12. Linear regression forecast of forest products employment in Douglas County, 1975-1990.

Source: Coos, Curry, Douglas Economic Improvement Association, Douglas County Population and Employment Projections, 1975-1990, (Roseburg, Oregon, March 1976): tables I and IV.

A second method of predicting the future of timber industry employment is to measure the past relationship between forest products employment and log harvest, and project the relationship forward in time (Wa11 and Oswald, 1975). A simple ratio of forest products industry employment to timber harvest is used to estimate changes in 
employment as a result of changes in timber harvest. The ratio represents the number of employees per million board feet harvested. A change in harvest should result in a corresponding change in employment. However, for the period 1958-1974 an examination of this ratio indicates that this relationship changes considerably over time (Figure 13). From 1958 to 1974, the ratio of the number of workers employed in the lumber and wood products industry per million board feet of timber harvested, ranged from a low of 3.51 in 1968 to a high of 5.78 in 1974. The coefficient of determination $\left(r^{2}\right)$ of the linear regression equation developed for employment and timber harvest from 1958 to 1974 was .06 , indicating an even weaker relationship than that demonstrated for time and employment.

The major shortcoming of the employment/timber harvest ratio, as demonstrated by the large variations in Figure 13 , is that it fails to discern that manufacturing, and not harvesting of trees is the major wood products employer in Douglas County. Fluctuations that influence manufacturing employment wi11 affect approximately 6,500 persons at the 1975 levels, whereas decisions on the levels of harvest will affect only 1,800 persons in logging (see page 16).

An underlying assumption of the employment-to-timber harvest ratio is that the timber harvest data are a surrogate of the actual amount of logs processed, or consumed, in the county. However this is not the case, as log exports, imports and other variables have a significant impact on the number of logs available for processing in the county. The difference between the number of board feet of logs felled in the forests within the county, and the number of board feet of logs 
processed by manufacturing plants within the county; is primarily accounted for by $\log$ exports to mills in adjacent counties; log imports from adjacent counties, and to a lesser degree by increases in the inventory of logs at local mills. These variables may help explain relatively low levels of employment in years of large harvest and vice versa.

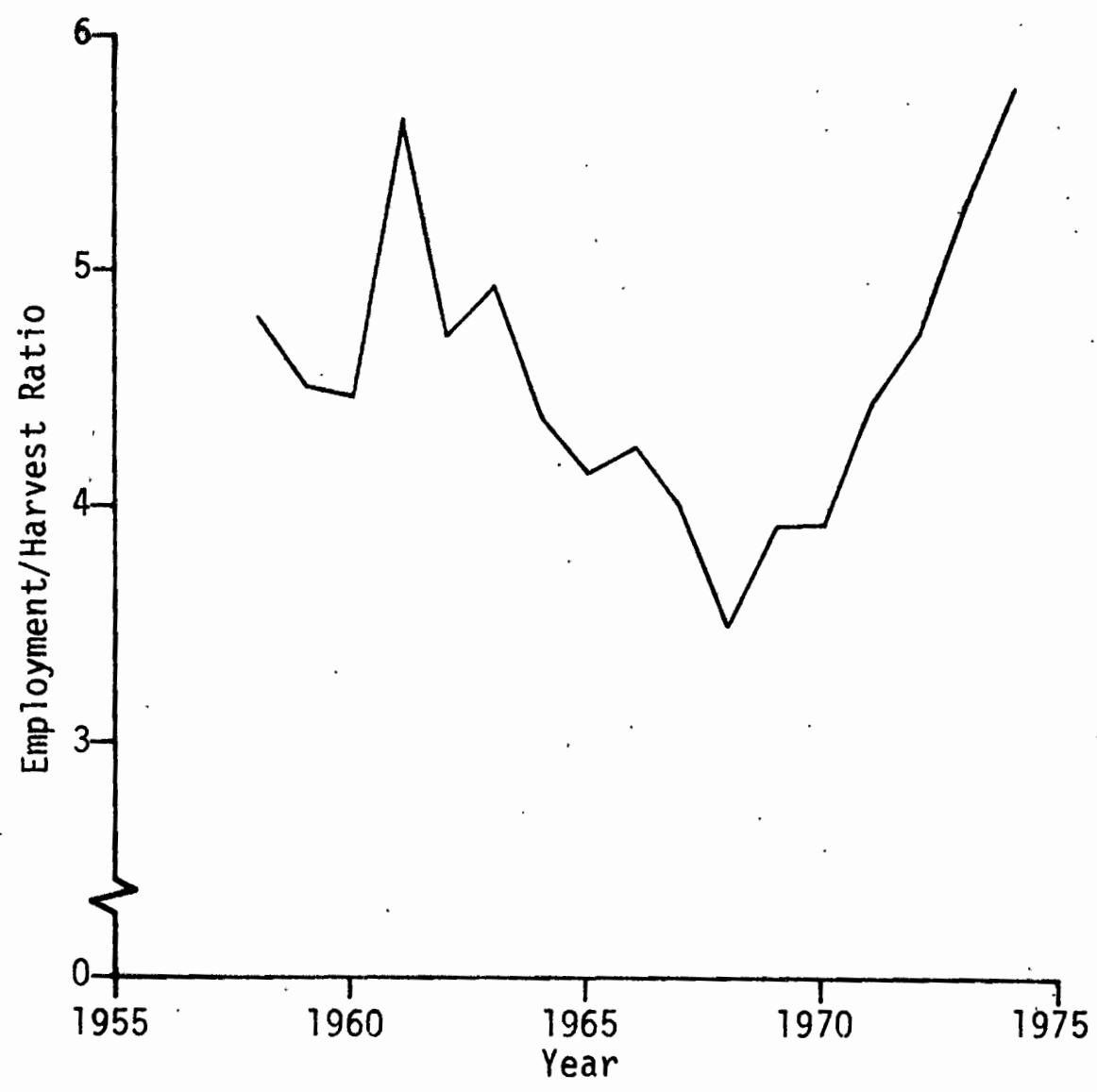

Figure 13. Ratio of lumber and wood products employment to million board feet of timber harvested.

Source: Brian R. Wa11, Log Production in Oregon and Washington: An Historical Perspective, PNW-42, (Pacific Northwest Forest and Range Experiment Station, Port1 and, Oregon, 1972): pp. 77-78, tables 42 through 54; Forest Survey Project, Oregon Timber Harvest (1971 through 1974), (Pacific Northwest Forest and Range Experiment Station, Portiand, Oregon, 1972-1975); C.C.D. Economic Improvement Association, Douglas County Population and Employment Projections, 1975-1990, (Roseburg, Oregon, March 1976): table IV. 
Table IX compares the timber harvest and consumption data for the three years for which consumption data are available. The difference between total harvest and total consumption indicates that Douglas County is historically a net exporter of timber.

\section{TABLE IX}

TIMBER HARVEST AND CONSUMPTION DATA FOR DOUGLAS COUNTY, OREGON 1966, 1968 AND 1972

\begin{tabular}{lccc}
\hline & Tota1 Harvest* & $\begin{array}{c}\text { Total } \\
\text { Consumption* }\end{array}$ & $\begin{array}{c}\text { Consumption as a } \\
\text { Percentage of } \\
\text { Total Harvest }\end{array}$ \\
\hline 1966 & $1,635,586$ & $1,065,802$ & 65.1 \\
1968 & $1,655,363$ & $1,135,218$ & 68.6 \\
1972 & $1,768,133$ & $1,408,881$ & 79.7 \\
\hline
\end{tabular}

* Mitlion Board Feet, $1 / 4$ inch International Rule

Source: Computed from John W. Austin, Timber Flows and Utilization Patterns in the Douglas-Fir Region, 1966, PNW-89, (Pacific Northwest Forest and Range Experiment Station, Portland, Oregon, 1969): pp. 40 and 41, table 7. Eugene R. Manock, Grover A. Choate, and Donald R. Gedney, Oregon Timber Industries 1968 Wood Consumption and Mill Characteristics. (State of Oregon Department of Forestry, Salem, Oregon, December 1970): pp. 48 and 49, table 4. John P. Schuldt and James 0. Howard, Oregon Forest Industries 1972 Wood Consumption and Mill Characteristics, (Oregon State University Extension Service, Corval7is, Oregon, December 1974): pp. 34, 35 and 36 , table 4.

Consumption of timber within Douglas County increased 32.2 percent between 1966 and 1972, while timber harvest increased only 8.1 percent. The logs for this increased consumption have come from increased imports, primarily Bureau of Land Management holdings in adjacent counties (see Table VII, page 31). However, Douglas County still remains a net exporter of timber. 
The reliability of the employment/harvest ratio is difficult to defend in view of the contradictory trends of increasing employment and decreasing harvest. The employment/consumption ratio shown in Table $X$ seems much more reliable as an indicator of future employment in Douglas County (even though only three data years are available) in view of the recent trends of increasing consumption and increasing employment. It will be used later in this report to examine future employment levels.

TABLE $X$

LOG CONSUMPTION AND FOREST PRODUCTS EMPLOYMENT IN DOUGLAS COUNTY, OREGON

\begin{tabular}{lccc}
\hline & Log Consumption* & $\begin{array}{c}\text { Forest Products } \\
\text { Employment }\end{array}$ & $\begin{array}{c}\text { Employment/ } \\
\text { Consumption Ratio }\end{array}$ \\
\hline 1966 & $1,065.802$ & 7,380 & $6.92: 1$ \\
1968 & $1,135.218$ & 7,590 & $6.69: 1$ \\
1972 & $1,408.881$ & 8,750 & $6.21: 1$ \\
\hline
\end{tabular}

* Million Board Feet, 1/4 Inch International Rule

Source: Computed from John W. Austin, Timber Flows and Utilization Patterns in the Douglas-fir Region, 1966, PNW-89, (Pacific Northwest Forest and Range Experiment Station, Portland, Oregon, 1969): pp. 40-41, table 7; Eugene R. Manock, Grover A. Choate and Donald R. Gedney, Oregon Timber Industries, 1968 Wood Consumption and Mill Characteristics, (State of Oregon, Department of Forestry, Salem, Oregon, December 1970): pp. 48-49, table 4; John P. Schuldt and James 0 . Howard, Oregon Forest Industries, 1972 Wood Consumption and Mill Characteristics, (Oregon State University Extension Service, Corval7is, Oregon, December 1974): pp. 34-35, table 4.

\section{FUTURE TIMBER CONSUMPTION}

Predicting future timber consumption levels within the county faces certain problems, the most important of which is that there is no 
guarantee that the present pattern of $\log$ flows will continue between Douglas County and other adjacent counties. The ability of Douglas County mills to competitively participate in the bidding process is an unknown. However, the increasing consumption of extra-county public timber by local mills indicates that local processors are presently successful in their efforts. Further increases in the consumption of public timber may be increasingly difficult as the: timber shortage becomes more acute and additional manufacturers enter the bidding process to obtain sufficient quantities of logs to keep their firms in business. For the purposes of this paper, it will be assumed that Douglas County mills will continue to receive the same percentage of harvest from public lands as they did in 1972. (.814 for national forests, 1.312 for Bureau of Land Management and 1.144 for State of Oregon lands).

The forecasting of private timber consumption by Douglas County mills faces several problems, one of which is similar to that of public timber consumption. From 1971 to 1974 the farmer and other private (non-industry) timber owner classification contributed an average annual harvest of 55,091 thousand board feet (Scribner Log Rule) or 8.3 percent of the total private timber harvest in the county (Oregon Timber Harvest, 1971 through 1974). The largest portion of this harvest is sold to the highest bidder, who may, in the future, be located outside of Douglas County. The ability of Douglas County mills to successfully bid on this source of supply is unknown, thus it will be assumed that the percentage of harvest consumed within the county in 1972 will be sustained into future years. 
With a decreasing timber supply projected, it seems certain that in time all major forest industry owners of commercial timber in Douglas County will cease selling timber to other forest industry firms, and process the timber in their own mill, as harvests in excess of requirements become an event of the past. Douglas County timber owners with processing plants outside of the county will ensure that all of their harvest goes to their plants, thus maintaining that segment of the net exports of private timber from Douglas County.

In 1966, exports of private timber were 50.6 percent of the total private timber harvest, in $1968,50.1$ percent, and in 1972, 58.9 percent (Austin, 1969; Manock et al., 1970; Schuldt et a1., 1974). The data presented for 1972 should be discounted as being representative of an average year, since almost all measures of timber harvest were dramatically affected by an increase of 55 percent in the average stumpage prices over the 1971 average (Oregon Timber Harvest, 1973), and private timber harvest levels are very responsive to price changes. This percentage increase was the largest increase experienced during the 19641974 period. The estimate which will be utilized in this paper is that future exports will remain at 50 percent of the total private timber harvest. Mr. Ernie Niemi of Alpha Research, a consultant to the Douglas Timber Operators, felt that although this percentage may vary over time, in the long run it should approximate 50 percent (private conversation with the author, 26 August 1976). Since the private timber industry is the major factor in the timber harvest decline as predicted by Hamill and Gedney (see page 26), if only 50 percent of that impact is applicable to Douglas County mills, then the decrease in timber-dependent 
employment may not be as severe as one may expect. The effect that this exporting of timber will have on the county is discussed in the following section.

\section{FUTURE TIMBER SUPPLIES}

To a large degree, the accuracy and reliability of timber supply forecasts are dependent upon the accuracy of the most current timber inventory data and knowledge of present and projected silviculture methods. The timber harvest forecasts from Timber for Oregon's Tomorrow (Beuter et al., 1976) were chosen for analysis of this report. The research was conducted by three staff members of the School of Forestry at Oregon State University in 1975 and provided an up-to-date timber inventory and information on timber management practices and growth needed for projecting future timber availability. A computer simulation model used this data base to make specific projections of possible changes in future timber harvest in Oregon.

As demonstrated by Table XI, which was computed from data used in Beuter's report (1976), the sustained-yield concept as appiied to public forest lands is predicted to perpetually maintain the public forest harvest. The "Other Private" owner classification is also expected by Beuter to maintain a stable harvest over the next thirty years. If current policies and trends continue, the "Forest Industry" owner class is expected to be able to maintain its current harvest until 1995, after which time it is projected to decline to between $531.6-525.2$ million board feet (Scribner Log Rule), or approximateiy 58 percent of the present timber harvest. 
TABLE XI

AVERAGE ANNUAL HARVEST* IN DOUGLAS COUNTY, OREGON, 1975-2005

\begin{tabular}{lrrr}
\hline Owner Class & $1975-1985$ & $1985-1995$ & $1995-2005$ \\
\hline National Forest & 458,400 & 458,400 & 458,400 \\
$\begin{array}{l}\text { Bureau of Land } \\
\text { Management }\end{array}$ & 317,700 & 317,700 & 317,700 \\
State of Oregon & 24,840 & 22,260 & \\
Forest Industry & 914,780 & 915,660 & 525,940 \\
& & & 531,600 \\
Other Private & 38,400 & 38,160 & 37,920 \\
All Owner Classes & $1,751,760$ & $1,752,180$ & $1,366,200-$ \\
& & & $1,372,560$ \\
\hline
\end{tabular}

* Thousand Board Feet, Scribner Log Rule

Source: Computed from data received in correspondence from Richard Gustafson, (Oregon State University Forest Research Laboratory, Corvali is, Oregon, July 1976).

The impact of this reduction upon the total timber harvest from all timber owners in Douglas County is to reduce the total timber harvest from 1,751.76 million board feet, to a range between 1,372.56 $1,366.2$ million board feet, or to approximately 78 percent of present harvest levels.

However, as stated on page 38, timber harvest is not the most critical factor affecting employment in Douglas County. As previously indicated, measurements of timber harvest are commoniy used as surrogate measures for timber consumption, and it is timber consumption that dictates employment for the majority of the lumber and wood products workers in the county at any point in time. 
In view of the sustained yield concept practiced on federal and state forests to maintain a specific level of harvest in perpetuity, the assumption made on page 42 that Douglas County will continue to consume 1972 levels of timber from public lands seems reasonable. If the harvest from private forest industry lands declines to 58 percent as predicted by Beuter in Table. XI, and if exports from private forest industry lands remain at 50 percent.as assumed on page 42 in this paper, then the consumption of timber from forest industry lands will approximate 262,620 thousand board feet (Scribner Log RuTe) annually in the 1995-2005 decade based on current policies and programs.

Table XII indicates the total log consumption by owner-class for Douglas County to the 1995-2005 decade as projected by the author, utilizing a 50 percent level of harvest as mentioned above for the consumption pattern of the private forest industry classification. The 1972 consumption/harvest ratios of .814 for National Forest, 1.312 for Bureau of Land Management holdings, 1.144 for State of Oregon 1ands, and .664 for the "Other Private" owner classification, as derived from Schuldt et a1. (1974), were employed to determine the future consumption for the other remaining sectors.

As demonstrated in Table XII, the total log consumption in Douglas County could be higher than the 1972 levels for the next two decades before declining. The increases would be 8.5 percent over 1972 consumption levels in the 1975-1985 decade and 8.4 percent in the decade following. The decline to approximately 1,110 million board feet in the third decade would be a decrease of between 7.2 and 7.5 percent compared to the 1972 consumption lever. Such forecasted consumption levels 
indicate that the declining timber resource base may not drastically lower employment levels in the local lumber and wood products industry by the year 2000 and that employment may actually increase over the next 20 years.

\section{TABLE XII}

PROJECTED AVERAGE ANNUAL LOG CONSUMPTION* IN DOUGLAS COUNTY, OREGON BY OWNER CLASS, 1975-2005.

\begin{tabular}{lrrr}
\hline Owner CTass & $1975-1985$ & $1985-1995$ & $1995-2005$ \\
\hline National Forest & 373,138 & 373,138 & 373,138 \\
$\begin{array}{l}\text { Bureau of Land } \\
\text { Management }\end{array}$ & 476,822 & 416,822 & 416,822 \\
State of Oregon & 28,417 & 25,465 & 30,819 \\
Forest Industry & 456,390 & 457,830 & $262,620-$ \\
& & & 265,800 \\
Other Private & 25,498 & 25,338 & 25,179 \\
All Timber Owners & $1,300,265$ & $1,298,593$ & $1,108,578-$ \\
& & & $1,111,758$
\end{tabular}

* Thousand Board Feet, Scribner Log Rule

\section{EMPLOYMENT CHANGES}

The Coos, Curry, Douglas Economic Improvement Association (1973) estimated that at present production levels, approximately 2.24 jobs are created in the rumber and wood products industry for every additional one-million board feet of timber processed. Gustafson (1975) estimated that the figure was closer to 2.02 when $\log$ flows to adjacent 
counties were evaluated. Table XIII demonstrates the changes from 1972 employment levels that might be expected from the changes in consumption levels within Douglas County over the next three decades using the ratios established by the CCDEIA and Gustafson.

\section{TABLE XIII}

POTENTIAL CHANGES IN EMPLOYMENT LEVELS IN THE LUMBER AND WOOD PRODUCTS INDUSTRY DUE TO CHANGES IN LOG CONSUMPTION 1975-2005

\begin{tabular}{lcccc}
\hline & Levels & $1975-1985$ & $1985-1995$ & $1995-2005$ \\
\hline CCDEIA & 8,970 & 9,198 & 9,195 & $8,679-8,776$ \\
Gustafson & 8,970 & 9,175 & 9,173 & $8,789-8,795$ \\
\hline
\end{tabular}

The changes shown in Table XIII are within \pm 2.5 percent of the 1972 annual average employment in the lumber and wood products industry, and are less than the seasonal employment changes that are inherent in the industry.

White the above exercise can provide a gross estimate of the effect that declining timber consumption can have upon employment, more accurate predictions necessitate discussing the timber consumption. pattern by forest products sector since each sector has different labor requirements for its processing needs.

As the primary economic activity in the processing of timber, logging supplies the raw materials for the secondary activities of sawmills and plywood and veneer mills, and is dependent upon the amount of timber harvested for its employment leveis. Sawmills and plywood and veneer mills however, compete for the logs harvested by the logging 
sector. Table XIV illustrates the consumption pattern of logs for the sawmill and plywood and yeneer sectors.

TABLE XIV

LOG CONSUMPTION PATTERNS IN DOUGLAS COUNTY, OREGON BY INDUSTRIAL SECTOR AS A PERCENTAGE OF TOTAL CONSUMPTION

\begin{tabular}{lrrr}
\hline Sector & 1966 & 1968 & 1972 \\
\hline Sawmil1s & 46.4 & 46.9 & 52.6 \\
Plywood and Veneer & 53.6 & 53.1 & 47.4 \\
Total & 100.0 & 100.0 & 100.0
\end{tabular}

Source: Computed from John W. Austin, Timber Flows and Utilization Patterns in the Douglas-fir Region, 1966, PNW-89, (Pacific Northwest Forest and Range Experiment Station, Portland, Oregon, 1969): p.31, table 5; Eugene R. Manock, Grover A. Choate, and Donald R. Gedney, Oregon Timber Industries 1968 Wood Consumption and Mill Characteristics, (State of Oregon Department of Forestry, Salem, Oregon, December 1970): pp. 64 and 88, tables 18 and 42; John P. Schuidt and James 0 . Howard, Oregon Forest Industries 1972 Wood Consumption and Mill Characteristics, Toregon State University Extension Service, Corvallis, Oregon, December 1974): pp. 53 and 79, tables 20 and 46.

Al though it may seem that sawmills are increasing their share of timber consumption within the county according to Table XIV, Mr. Jim Zelenka, Senior Economic Planner for the CCDEIA in a personal conversation with the author (18 August 1976), stated that the 1972 figures were skewed by the vagaries of the market place and do not reflect long term trends. According to Mr. Zelenka, the recession in housing starts in 1972 drastically lowered demand for plywood, but the demand for dimension lumber was not as seriousiy affected.

Reports issued by Wall (1969) and Oswald (1973) projected that the 
consumption ratios for sawmills and veneer and plywood mills in coastal Oregon would remain at the 1968 levels shown in Table XIV. However, this should be tempered with the displacement of plywood by particleboard, hardboard and other similar substitutes made from wood by-products that has occurred since that time. For the purposes of this paper, the consumption pattern by industry sector to the year 2000 is assumed to be 50 percent sawmill consumption and 50 percent plywood and veneer mill consumption, closely approximating the percentages in Table XIV.

Multiplication of the projected total consumption levels in Douglas County (Table XII, page 47) by these percentages results in TabTe XV.

\section{TABLE XV}

SAWMILL AND VENEER AND PLYWOOD MILL CONSUMPTION* IN DOUGLAS COUNTY, OREGON, 1975-2005

\begin{tabular}{lrrr}
\hline Sector & $1975-1985$ & $1985-1995$ & $1995-2005$ \\
\hline Sawmil1s & 650,132 & 649,296 & $554,289-555,879$ \\
Piywood and Veneer & $\underline{650,132}$ & $\underline{649,296}$ & $\underline{554,289-555,879}$ \\
$\quad$ Total & $1,300,265$ & $1,298,592$ & $2,208,578-1,111,758$
\end{tabular}

* Thousand Board Feet, Scribner Log Rule.

Utilizing Wall and Oswald's (1975) estimate of the 1975 levels of productivity per million board feet as a constant for each sector (see page 34 ) and multiplying by the above consumption levels for sawmills and for veneer and plywood mills, and then by total timber harvest for logging, results in future employment levels as they may be affected by the reduction in available timber supply. Table XVI demonstrates the 
estimated average annual employment in each sector for the next three decades in comparison to the 1975 employment levels.

TABLE XVI

IMPACTS OF REDUCED TIMBER AVAILABILITY ON EMPLOYMENT, 1975-2005

\begin{tabular}{lcccc}
\hline Sector & 1975 actual & $1975-1985$ & $1985-1995$ & $1995-2005$ \\
\hline Logging & 1,780 & 1,854 & 1,852 & 1,583 \\
Sawmi17s & 2,240 & 2,022 & 2,019 & 1,726 \\
$\begin{array}{l}\text { Veneer and } \\
\text { Plywood }\end{array}$ & 3,610 & 3,738 & 3,733 & 3,191 \\
Total & 7,630 & 7,614 & 7,604 & \\
\hline
\end{tabular}

It is readily apparent from the evidence shown in Table XVI that the availability of raw materials for the forest products industries in Douglas County will have only very minor effects over the next two decades, while in the third decade accounting for a reduction in employment of 1,130 persons, or 14.8 percent less than 1975 levels.

However, when the consumption levels in Table XV are multiplied by the projected productivity estimates per million board feet developed by Wa17 and Oswald (1975) and discussed on page 34 of this study, the result is Table XVII, showing projected decreased employment levels in the forest products industry.

As demonstrated by Table XVII, productivity increases per employee are expected to have a greater effect than a declining timber resource base upon future employment in the forest products industries. In the first decade productivity should account for 1,087 of the 1,103 jobs estimated to be lost from 1975 levels. In the second decade, 2,767 of 
2,793 jobs, and in the third, 3,388 of 4,518. The remaining employment losses can be contributed to the declining timber resource base. During the first two decades productivity increases will account for 99 percent of the decreases in forest products employment levels and for 75 percent in the third decade. In the next thirty years Douglas County could lose. over 50 percent of the present employment in lumber and wood products. Table XVIII demonstrates the effect that such an occurrence would have on total employment levels in the county.

\section{TABLE XVII}

PROJECTED EMPLOYMENT LEVELS IN FOREST PRODUCTS INDUSTRIES 1975-2005

\begin{tabular}{lcccc}
\hline Sector & 1975 actual & $1975-1985$ & $1985-1995$ & $1995-2005$ \\
\hline Logging & 1,780 & 1,768 & 1,597 & $1,219-1,222$ \\
Sawmills. & 2,240 & 1,671 & 1,130 & $659-661$ \\
$\begin{array}{l}\text { Veneer and } \\
\text { Plywood }\end{array}$ & 3,610 & 3,088 & 2,110 & $1,231-1,234$ \\
Total & - & - & - & \\
\hline
\end{tabular}

Table XVIII uses the multipliers derived by Youmans et al. (1973) for each of the forest products sectors to detail the cumulative effects of reduced forest products employment (see Table IV, page 22). Such multipliers represent the impact of increasing or decreasing the economic activity in any specific sector upon the entire county economy. Multiplying the reduction in employment projected for each sector by the multiplier derived for each sector (Table IV) should generate an approximate number of the total employment opportunities that may be lost in each of the next three decades. This methodology may tend to overstate 
the effect of the loss of employment opportunities in the forest products industry upon total employment in the county. Some persons may be satisfied with lower incomes and/or part-time employment in order to avoid being unemployed. As a result the actual numbers of employed may not decline to the extent indicated in Table XVIII.

The multipliers shown in Table IV are income or expenditure multipliers. Their use in employment calculations is subject to academic question, however as a practical matter multipliers are often used interchangeably, particularly if only one of the multiplier measurements (income or employment) exists. The author believes their use in this analysis is justified. Economic base analysis generates an employment multiplier approximately equal to the average income multiplier for all industries in Douglas County of 2.53 (see page 22) from the input-output analysis by Youmans et a1. (1973).

Calculation of the multiplier utilizing the formula, Multiplier $=\left(1+\frac{\text { employment in non-basic }}{\text { employment in basic }}\right)$ from Berry and Horton (1970) is as follows:

1975 Total non-agricultural wage and salary employment 30,440 persons 1975 Basic employment

\begin{tabular}{lr} 
Manufacturing & 9,950 \\
Federal employment & 1,520 \\
Tourism & \\
\hline
\end{tabular}

Total 11,970 persons

1975 Non-basic employment 18,470 persons

$$
\text { Multiplier }=\left(1+\frac{18,470}{11,970}\right)=1+1.54=\underline{\underline{2.54}}
$$


Such results indicate that the income multiplier may be substituted for the employment multiplier without major discrepancies. The income multipliers for each sector of the lumber and wood products industry are also thought to approximate the employment multiplier for each sector. Sawmills have the highest multiplier of the three sectors for several reasons. First, they do contribute a fairly high value added to the product with resultant high wages paid to employees and, second, a large amount of the capital equipment needs and supplies for local mills can be supplied from firms in Douglas County. Reasoning along similar lines would demonstrate that plywood and veneer milis have much lower multipliers. The high value added and high wage levels are offset by the inability of local firms to supply the sophisticated equipment necessary for such plants. Similarly, logging would also, have lower multipliers due to the lower value added that it contributes to the product al though many of this sector's needs can be supplied locally.

The impact that a loss of basic employment in the forest products industry can have upon the local economy is very significant as shown by Table XVIII. 


\section{TABLE XVIII}

PROJECTED TOTAL EMPLOYMENT CHANGES IN DOUGLAS COUNTY AS A RESULT OF CHANGES IN EMPLOYMENT IN THE LOCAL FOREST PRODUCTS SECTORS 1975-2005

\begin{tabular}{|c|c|c|c|c|}
\hline Employment & Logging & Sawmills & $\begin{array}{l}\text { Veneer \& } \\
\text { Plywood }\end{array}$ & Total \\
\hline $\begin{array}{l}\text { 1975-1985 } \\
\text { Forest } \\
\text { Products } \\
\text { Total } \\
\text { Employment }\end{array}$ & $\begin{array}{l}-\quad 12 \\
-\quad 30\end{array}$ & $\begin{array}{l}-569 \\
-7,758\end{array}$ & $\begin{array}{l}-522 \\
-1,248\end{array}$ & $\begin{array}{l}-1,103 \\
-3,036\end{array}$ \\
\hline $\begin{array}{l}\text { 1985-1995 } \\
\text { Forest } \\
\text { Products } \\
\text { Total } \\
\text { Employment }\end{array}$ & $\begin{array}{r}-183 \\
-\quad 456\end{array}$ & $\begin{array}{l}-1,110 \\
-3,430\end{array}$ & $\begin{array}{l}-1,500 \\
-3,585\end{array}$ & $\begin{array}{l}-2,793 \\
-7,471\end{array}$ \\
\hline $\begin{array}{l}\text { 1995-2005 } \\
\text { Forest } \\
\text { Products } \\
\text { Tota1 } \\
\text { Employment }\end{array}$ & $\begin{array}{r}-560 \\
-1,394\end{array}$ & $\begin{array}{l}-1,580 \\
-4,882\end{array}$ & $\begin{array}{l}-2,378 \\
-5,683\end{array}$ & $\begin{array}{l}-4,518 \\
-11,959\end{array}$ \\
\hline
\end{tabular}


CHAPTER VI

SUMMARY AND CONCLUSIONS

The purpose of this study was to measure the aggregate impact of a declining timber resource base and increasing productivity upon employment in Douglas County, Oregon. The study has demonstrated that timber consumption rather than timber harvest is the more important criterion for evaluating employment levels in the county. Log flows to and from adjacent counties have a considerable influence over the amount of logs processed within the county and greatly distort the reliability of an employment/harvest ratio.

Utilizing the most recent timber harvest forecast for the county through the year 2000 and assuming that the pattern of $\log$ flows to and from Douglas County would remain at or about 1972 levels and labor force productivity would remain at or about 1975 levels, resulted in projected relatively stable employment levels for lumber and wood products over the next two decades and minor reductions of less than 15 percent in the third decade.

However, increasing productivity in all sectors of the lumber and wood products industry in the county has been a historic factor accounting for decreasing employment levels in the industry. Linear regression equations developed by the U.S. Forest Service to project productivity increases for all sectors of the forest products industry have indicated that this factor may be the most critical element in determining future employment levels in Douglas County. Due principaliy to increasing 
productivity, future employment levels in the lumber and wood products industry may approach 3,110 persons in the year 2000, or a loss of approximately 4,500 persons from 1975 levels.

Whereas the factors of a declining timber resource base and increasing productivity will tend to reduce employment in lumber and wood products, other factors are working toward stabilized or increased employment.

First, current research in forest genetics and reforestation methods has developed "super trees" which grow faster and reach merchantable size in fewer years. The result is a 15 percent increase in timber harvest. However, current planting of "super trees" will not be a major factor in the county's timber harvest until after the year 2000 , or beyond the time frame of this study.

Second, immense quantities of wood chips are being generated primarily as by-products of logging and milling (which were previously burned or exported) and are being increasingly utilized in manufacturing. A total of $2,091,916$ tons of wood residues were generated by mills within the county in 1972, much of which was shipped to Japan or pulp and paper plants in the Willamette Valley (Schuldt et al., 1974). The CCDEIA, in its Central Douglas County Area Development Factbook (1976c), indicated that in addition to the pulp, paper, particleboard and hardboard which are presently manufactured in Douglas County from wood chips, other products that could utilize the wood fibers included: 
ethyl alcohol

roofing materials

tanning extracts

toys

charcoal

novelties

absorbents packing

concrete

molded articles

briquette fuel

plasters

plastics

sweeping compounds composition floors

agricultural uses

fertilizers

mulch

feed supplements

meat smoking fuel

insulation

Third, with a declining log supply it seems reasonable to assume that mills within the county would be reluctant to invest heavily in new capital equipment to increase productivity, al though such capital expenditures may be necessary to maintain a competitive cost of production position. The result of this may be much smaller productivity increases than estimated by Wall and Oswald (1975), and a larger number of employees per million board feet than arrived at in Chapter $V$ of this paper.

Fourth, hardwoods represent a major undeveloped resource in the county with good possibilities for development. The dominance of the conifer softwoods in the forest products industry has hindered the development possibilities of the deciduous hardwoods. Douglas County, especially in the coastal area, has large stands of commercially valuable hardwood, primarity Red Alder and Tan Oak. Beuter et al. (1976) estimated that hardwoods will account for 15 percent to 25 percent of the total harvest in these coastal portions over the next thirty years. The greatest potential for utilization of this resource seems to lie in the production of household and novelty items, sports equipment and custom fashioned furniture. 
Fifth, Douglas County produces an enormous amount of lumber and plywood, almost all of which is transported out of the county to undergo further processing by many firms. Some of the tertiary processing sectors that utilize this resource, and which may be attracted to the area include millwork, structural wood beams and supports, furniture, partitions, shelving, and office and store fixtures. The largest consumer of wood products from Douglas County is the housing industry where utilization of lumber and plywood takes place on the construction site. The increasing trend toward the manufacture of prefabricated houses and components offers an opportunity for local firms to serve both the Pacific Northwest and California housing markets due to the county's central location between the two population centers.

Sixth, the sustained timber harvest from commercial timberlands could be greater if all public and private forest lands were administered through voluntary coordinated planning as a single management unit rather than by separate ownerships. Since public lands are administered independentiy of private forests, with their own sustained yield programs, the current public timber harvest policies do not take into account the fact that most private forest lands will again be brought into production as the second growth timber matures (CCDEIA, 1976c). If this fact were accounted for by public management, the allowable cut from public lands could be substantially larger and still maintain the sustained yield concept for the total commercial timberlands within the county.

The implication of this study for the elected officials of Douglas County and for the Coos, Curry, Douglas Economic Improvement Association, 
as the Economic Development District for the area, is that a concerted effort should be undertaken to expand employment in the county to replace jobs lost in the forest products industry. Such efforts should not rely exclusively upon the six factors mentioned above for several reasons. First, it is unknown if a large enough number of firms engaged in these sectors could be attracted to the county, or commence operations here, to offset the estimated loss of 4,518 employment opportunities in the lumber and wood products industries. Secondly, catastrophic occurrences, such as a devastating insect infestation or a major conflagration could destroy a large percentage of the resource base upon which all forest products industries are dependent. The recruitment of industries to the county should focus upon diversifying the economy away from its historic base of the forest products industries. 


\section{SELECTED REFERENCES}

Austin, John W. Timber Flows and Utilization Patterns in the Douglasfir Region, 1966. Portland, Oregon: U.S. Department of Agriculture, Forest Service, Pacific Northwest Forest and Range Experiment Station, 1969.

Bassett, Patricia M. and Choate, Grover A. Timber Resource Statistics for Oregon, January 1, 1973. Portland, Oregon: U.S. Department of Agriculture, Forest Service, Pacific Northwest Forest and Range Experiment Station, 1974.

Beuter, John H.; Johnson, K. Norman; Scheurman, H. Lynn. Timber for Oregon's Tomorrow. Corvallis, Oregon: Oregon State University, Forest Research Laboratory, January 1976.

Berry, Brian J. L. and Horton, Frank E. Geographic Perspectives on Urban Systems. Englewood Cliffs, New Jersey: Prentice-Ha11, Inc., 1970.

Beyers, William B. "On Geographical Properties of Growth Center Linkage Systems" (mimeographed). Seattle, Washington: Department of Geography, University of Washington, undated.

Blalock, Hubert M. Social Statistics, Second Edition. New York: McGraw-Hil1 Book Company, 1972.

Bureau of Governmental Research and Service. The Significance of the 0 \& C Forest Resource in Western Oregon. Eugene, Oregon: Bureau of Governmental Research and Service, University of Oregon, 1968.

Center for Population Research and Census. State of Oregon, Population Projections for Oregon and Its Counties: 1975-2000. Portland, Oregon: Center for Population Research and Census, Portland State University, February 1976.

Coos, Curry, Douglas Economic Improvement Association. "Presentation for the Oregon State Forester" (mimeographed). Roseburg, Oregon: Coos, Curry, Douglas Economic Improvement Association, October 9, 1973.

- Douglas County Population and Employment Projections, 19751990. Roseburg, Oregon: Coos, Curry, Douglas Economic Improvement Association, March 1976.

- Central Douglas County Area Development Factbook. Roseburg, Oregon: Coos, Curry, Douglas Economic Improvement Association, June 1976. 
- Overall Economic Development Plan Revised 1976 Action Program. Roseburg, Oregon: Coos, Curry, Dougias Economic Improvement Association, September 1976.

Darr, David R. and Fight, R. D. Douglas County, Oregon: Potential Economic Impacts of a Changing Timber Resource Base. PortTand, Oregon: U.S. Department of AgricuTture, Forest Service, Pacific Northwest Forest and Range Experiment Station, 1974.

Douglas County Planning Commission. The Character of Douglas County. Roseburg, Oregon: Douglas County PTanning Commission, 1968 revision.

Fernstrom, John R. "Bringing In The Sheaves". Corvall is, Oregon: Oregon State University Extension Service, 1973.

Gedney, Donald. Pacific Northwest Forest and Range Experiment Station, Portland, Oregon. Telephone conversation. 14 July 1976.

Gedney, Donald R.; Oswald, Daniel D.; Fight, Roger D. Two Projections of Timber Supply in the Pacific Coast States. Portland, Oregon: U.S. Department of Agriculture, Forest Service, Pacific Northwest Forest and Range Experiment Station, 1975.

Grantham, John B. Status of Timber Utilization on the Pacific Coast. Portiand, Oregon: U.S. Department of Agriculture, Forest Service, Pacific Northwest Forest and Range Experiment Station, 1974.

Gudger, Charles M. and Smith, Royce C. An Inquiry Into the Economic Potential of Douglas County, Oregon: 1971-1985. Corvaliis, Oregon: Oregon State University, School of Business and Technology, June 1972.

Gustafson, Richard Da7e. "Regional Employment Impacts of Timber Harvest Changes in Oregon." Master's Thesis, Oregon State University, Corvallis, Oregon, June 1975.

Oregon State University, Forest Research Laboratory, Corvallis, Oregon. Material received in correspondence. 24 July 1976

Hami11, Louis. A Forecast of the Forest Resource and Industry of Douglas and Lane Counties. Eugene, Oregon: University of Oregon, Bureau of Business Research, 1963.

Howard, James. Pacific Northwest Forest and Range Experiment Station. Portland, Oregon. Telephone conversation. 23 July 1976.

MacLean, Colin. Timber Resources of Douglas County, Oregon. Portland, Oregon: U.S. Department of Agriculture, Forest Service, Pacific Northwest Forest and Range Experiment Station, 1976. 
Maki, Wilbur R. and Schweitzer, Dennis L. Importance of Timber-Based Employment to the Douglas-fir Region, 1959 to 1971 . Portland, Oregon: U.S. Department of Agriculture, Forest Service, Pacific Northwest Forest and Range Experiment Station, June 1973.

Manock, Eugene R.; Choate, Grover A.; Gedney, Donald R. Oregon Timber Industries 1968 Wood Consumption and Mill Characteristics. Salem, Oregon: State of Oregon Department of Forestry, December 1970.

Murray, Thomas J. and Associates. Oregon's Timber Resource. Portland, Oregon: Thomas J. Murray and Associates, September 1966.

News-Review, The. "Timber". Roseburg, Oregon: February 5, 1977.

Niemi, Ernie. Alpha Research, Roseburg, Oregon. Consultant to Douglas Timber Operators. Interview. 26 August 1976.

Oregon Coastal Conservation and Development Commission. Economic Survey and Analys is of the Oregon Coastal Zone. Eugene, Oregon: Oregon Coastal Conservation and Development Commission, December 1974.

Oregon Department of Economic Development. Directory of Oregon Manufacturers 1976-1977. Portland, Oregon: State of Oregon, Department of Economic Development, January 1976.

Oregon Department of Employment. The Effects of Technological Change on Employment in the Lumber Industry. Salem, Oregon: State of Oregon, Department of Employment, January 1968.

Oregon State University Extension Service. Douglas County, Oregon Resource Atlas. Corvallis, Oregon: Oregon State University Extension Service, May 1973.

Oswald, Daniel D. Forest Resources and Forest Industrial Development in the Oregon Coastal Study Area. Portland, Oregon: U.S. Department of Agriculture, Forest Service, Pacific Northwest Forest and Range Experiment Station, Apri1 1973.

Pacific Northwest Forest and Range Experiment Station. Douglas-fir Supply Study: Alternative Programs for Increasing Timber Supplies from National Forest Lands. Portland, Oregon: U.S. Department of Agriculture, Forest Service, Pacific Northwest Forest and Range Experiment Station, 1969.

- Oregon Timber Harvest (1971 through 1974). Portland, Oregon: U.S. Department of AgricuTture, Forest Service, Pacific Northwest Forest and Range Experiment Station, Forest Survey Project, 1972 through 1975.

Report of the President's Advisory Panel on Timber and the Environment.

Fred A. Seaton, Chairman. Washington, D.C.: U.S. Government Printing Office, 1973. 
Rich, Stuart U. Marketing of Forest Products: Text and Cases. New York: McGraw-Hill Book Company, 1970.

Schuldt, John P. and Howard, James 0. Oregon Forest Industries 1972 Wood Consumption and Mill Characteristics. Corvallis, Oregon: Oregon State University Extension Service, December 1974.

Smith, David M. Industrial Location. New York: John Wiley and Sons, Inc., 1971.

Thoman, Richard S. and Corbin, Peter B. The Geography of Economic Activity, Third Edition. New York: McGraw-Hill Book Company, 1974.

Tiebout, Charles M. The Community Economic Base Study. New York: Committee for Economic Development, 1962.

Umpqua Regional Council of Governments. Comprehensive Manpower Plan, Fiscal Year 1976-77. Roseburg, Oregon: Umpqua Regional Council of Governments, District Six Manpower Planning Board, January 1976.

U.S. Department of Agriculture, Forest Service. The Outlook for Timber in the United States. Washington, D.C.: U.S. Government Printing Office, 1973.

Wal1, Brian R. Projected Developments of the Timber Economy of the Columbia-North Pacific Region. Port7and, Oregon: U.S. Department of Agricuiture, Forest Service, Pacific Northwest Forest and Range Experiment Station, 1969.

- Log Production in Washington and Oregon: An Historical Perspective. Portland, Oregon: U.S. Department of Agriculture, Forest Service, Pacific Northwest Forest and Range Experiment Station, 1972.

- Relationship of Log Production in Oregon and Washington to Economic Conditions. Port7and, Oregon: U.S. Department of Agriculture, Forest Service, Pacific Northwest Forest and Range Experiment Station, 1972.

- Employment Implications of Projected Timber Output in the Douglas-fir Region, 1970-2000. Portland, Oregon: U.S. Department of Agriculture, Forest Service, Pacific Northwest Forest and Range Experiment Station, 1973.

Wal 1, Brian R. and 0swald, Daniel D. A Technique and Relationships for Projections of Employment in the Pacific Coast Forest Industries. Portland, Oregon: U.S. Department of Agriculture, Forest Service, Pacific Northwest Forest and Range Experiment Station, 1975. 
65

Yates, Maurice. An Introduction to Quantitative Analyst is in Human Geography. New York: McGraw-Hi11 Book Company, 1968.

Yates, Maurice and Garner, Barry. The North American City. New York: Harper \& Row, Publishers, Inc., 1971

Youmans, Russel C.; Darn, David R.; Fight, Roger; Schweitzer, Dennis L. Douglas County, Oregon: Structure of a Timber County Economy. Corvallis, Oregon: Oregon State University, Agricultural Experimont Station, December 1973.

Zelenka, Jim. Coos, Curry, Douglas Economic Improvement Association, Senior Economic Analyst. Personal Communication. 18 August 1976. 


\section{GLOSSARY}

Allowable Cut: The amount of forest products that may be harvested annualiy or periodicaliy from a specified area over a stated period of time in accordance with the objectives of management.

Board Foot: The amount of timber equivalent to a piece 12 inches square and 1 inch thick.

Commercial Forest: Forest lands capable of producing 20 cubic feet per acre per year of industrial wood and not withdrawn from timber utilization.

Forest Management: The practical application of scientific, economic and social principles to the administration of a forest estate for specified objectives.

Intensive Forest Management: The practice of forest management so as to attain a sustained high level of volume and quality of output per area unit, through the application of the best techniques of silviculture and management.

International 1/4 Inch Scale: - The standard board-foot log rule adopted nationally by the U.S. Forest Service for the presentation of Forest Survey timber volume statistics.

Ownership Classifications:

National Forest Lands: Federal lands which have been designated by Executive Order or statute as National Forests and other lands under the administration of the U.S. Forest Service.

Other Public Lands: Federal lands other than National Forests, and administered by the Bureau of Land Management or Iands owned by the state, counties, and other local public entities.

Forest Industry Lands: Lands owned by companies or individuals operating wood-using plants, or whose primary operation is growing wood for industrial use.

Other Private Lands: All private lands except those classified as forest industry lands.

Particleboard: A panel manufactured from woody particles and bonded together with binders under heat and pressure.

Scribner Log Rule: The common board-foot log rule used in the Douglasfir region to determine the volume of sawtimber. Scribner Log Rule 
averages about 85 percent of the volume as measured by the International 1/4 Inch Rule.

Stumpage Value: The value of the timber as it stands uncut in terms of an amount per cubic foot.

Timber Consumption: The amount of logs in board-foot measure processed in manufacturing plants during a specified time period.

Timber Harvest: The amount of trees in board-foot measure logged during a certain time period. 